\title{
The Dzhungarian fault: Late Quaternary tectonics and slip rate of a major right-lateral strike-slip fault in the northern Tien Shan region
}

\author{
G. E. Campbell, ${ }^{1}$ R. T. Walker, ${ }^{2}$ K. Abdrakhmatov, ${ }^{3}$ JL. Schwenninger, ${ }^{4}$ J. Jackson, ${ }^{1}$ \\ J. R. Elliott, ${ }^{2}$ and A. Copley ${ }^{1}$ \\ Received 8 April 2013; revised 5 August 2013; accepted 7 September 2013.
}

[1] The Dzhungarian strike-slip fault of Central Asia is one of a series of long, NW-SE right-lateral strike-slip faults that are characteristic of the northern Tien Shan region and extends over $300 \mathrm{~km}$ from the high mountains into the Kazakh Platform. Our field-based and satellite observations reveal that the Dzhungarian fault can be characterized by three $100 \mathrm{~km}$ long sections based on variation in strike direction. Through morphological analysis of offset streams and alluvial fans, and through optically stimulated luminescence dating, we find that the Dzhungarian fault has a minimum average late Quaternary slip rate of $2.2 \pm 0.8 \mathrm{~mm} / \mathrm{yr}$ and accommodates $\mathrm{N}$-S shortening related to the India-Eurasia collision. This shortening may also be partly accommodated by counterclockwise rotation about a vertical axis. Evidence for a possible paleo-earthquake rupture indicates that earthquakes up to at least $M w 7$ can be associated with just the partitioned component of reverse slip on segments of the central section of the fault up to $30 \mathrm{~km}$ long. An event rupturing longer sections of the Dzhungarian fault has the potential to generate greater magnitude earthquakes ( $M w 8)$; however, long time periods (e.g., thousands of years) are expected in order to accumulate enough strain to generate such earthquakes.

Citation: Campbell, G. E., R. T. Walker, K. Abdrakhmatov, JL. Schwenninger, J. Jackson, J. R. Elliott, and A. Copley (2013), The Dzhungarian fault: Late Quaternary tectonics and slip rate of a major right-lateral strike-slip fault in the northern Tien Shan region, J. Geophys. Res. Solid Earth, 118, doi:10.1002/jgrb.50367.

\section{Introduction}

[2] The Tien Shan of central Asia (Figures 1 and 2) is dominated both by $\mathrm{E}-\mathrm{W}$ range-front thrust faults [e.g., Mushketov, 1890; Tapponnier and Molnar, 1979; Thompson et al., 2002] and by long NW-SE right-lateral strike-slip faults [Voitovich, 1969; Tapponnier and Molnar, 1979; Burtman et al., 1996; Selander et al., 2012] that cut through the interior of the Tien Shan, such as the TalasFergana and Dzhungarian faults. Subordinate ENE-WSW left-lateral strike-slip faults are also present [Tapponnier and Molnar, 1979]. A number of NW-SE faults, such as the Karatau, Dzhalair-Naiman, Aktas, and Chingiz faults [Suvorov, 1963, 1973; Tapponnier and Molnar, 1979], also exist within the Kazakh Platform north of the Tien Shan (Figure 1b). These faults are Paleozoic structures [Suvorov, 1963, 1973; Tapponnier and Molnar, 1979], and it is not

\footnotetext{
${ }^{1}$ Bullard Laboratories, Department of Earth Sciences, University of Cambridge, Cambridge, UK.

${ }^{2}$ Department of Earth Sciences, University of Oxford, Oxford, UK.

${ }^{3}$ Kyrgyz Institute of Seismology, Bishkek, Kyrgyzstan.

${ }^{4}$ Research Laboratory for Archaeology and the History of Art, University of Oxford, Oxford, UK.
}

Corresponding author: G. E. Campbell, Bullard Laboratories, Department of Earth Sciences, University of Cambridge, Cambridge CB3 0EZ, UK. (gc416@cam.ac.uk)

(C)2013. American Geophysical Union. All Rights Reserved. 2169-9313/13/10.1002/jgrb.50367 clear whether they have been reactivated during the late Cenozoic. GPS velocities [Zubovich et al., 2010] show that 1-2 $\mathrm{mm} / \mathrm{yr}$ of shortening must be accommodated north of the Tien Shan, and rare, deep earthquakes in the Platform (Figure 2) suggest that such Platform-interior faults, if reactivated, may have the potential to generate large earthquakes, although very rarely.

[3] The E-W thrust and ENE-WSW left-lateral faults are known to have generated large magnitude, destructive earthquakes: The 1992 Ms 7.3 Suusamyr earthquake of Kyrgyzstan [Mellors et al., 1997; Ghose et al., 1997] (Figure 1b) occurred on an E-W thrust fault, and the $1911 \mathrm{Ms}$ 8.2 Chon-Kemin event on a ENE-WSW reverse left-lateral fault [Bogdanovich et al., 1914] (Figure 1b). By contrast, the long NW-SE right-lateral strike-slip faults within the Tien Shan, although known to be active and conspicuous in satellite imagery [Voitovich, 1969; Trifonov, 1978; Tapponnier and Molnar, 1979; Burtman et al., 1996], are associated with no substantial historical earthquakes, at least over the last 200 years (Figure 1b).

[4] This paper is concerned with one of the long NWSE range-interior right-lateral strike-slip faults. The best known example is the Talas-Fergana fault, which extends $\sim 800 \mathrm{~km}$ from north of Kashgar $\left(39^{\circ} \mathrm{N}, 75^{\circ} \mathrm{E}\right.$; Figure 1a) to $44^{\circ} \mathrm{N}, 67^{\circ} \mathrm{E}$ in Kazakhstan. Within the Tien Shan interior, the Talas-Fergana fault has an upper bounds slip rate of $\sim 10 \mathrm{~mm} / \mathrm{yr}$ [Burtman et al., 1996; Korjenkov et al., 2010], though GPS velocity measurements show only $1-3 \mathrm{~mm} / \mathrm{yr}$ of 


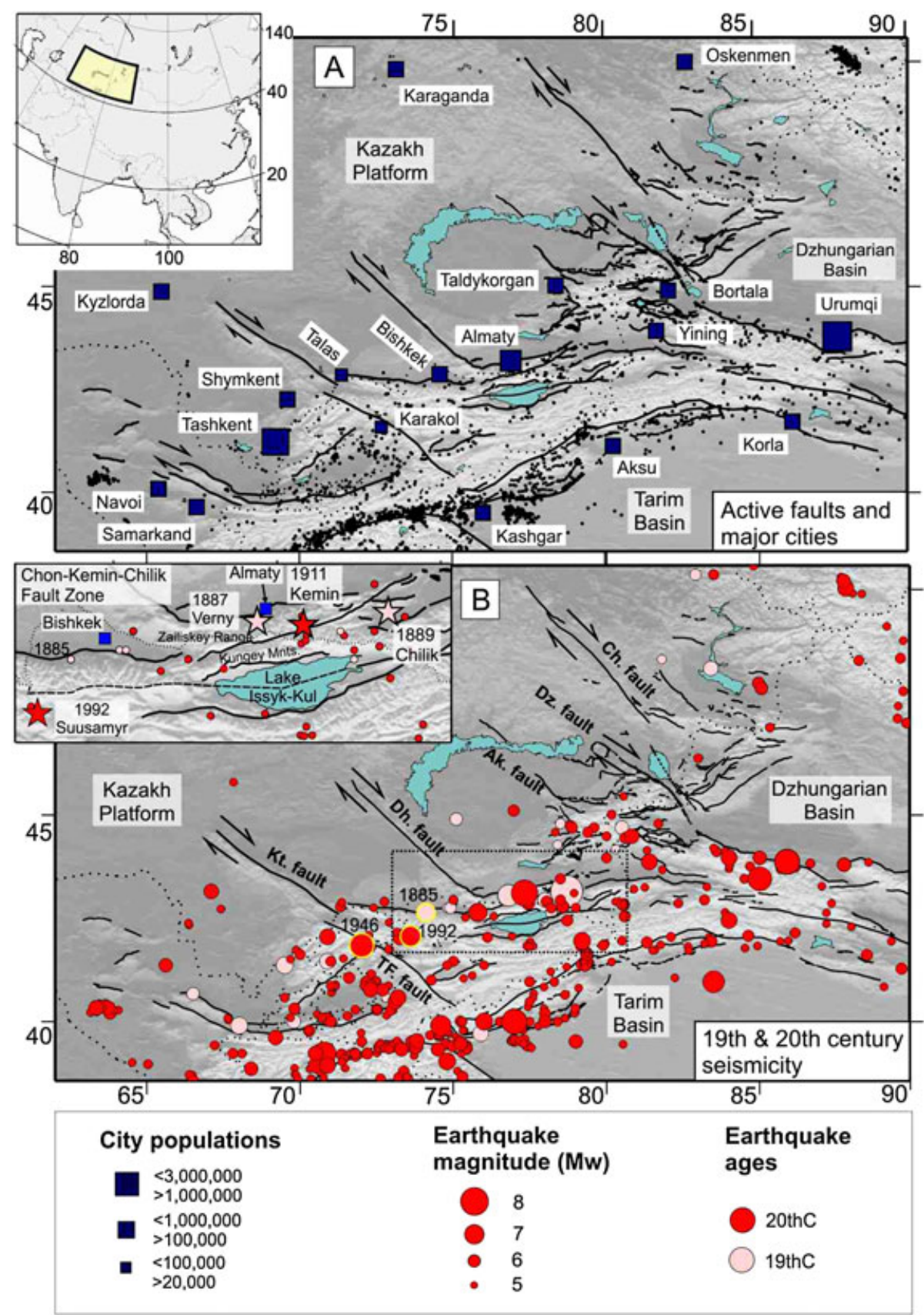

Figure 1. Major cities, active faults, and historic seismicity of the northern Tien Shan region. Country boundaries are dashed in black. (a) Several major cities (dark blue squares) with populations of over one million people - including Almaty which has been destroyed by a series of $M s>7$ earthquakes in the last two centuries (see Figure 11b). Engdahl earthquake catalog $M w \geq 3$ are shown as black dots [Engdahl et al., 1998]. (b) Seismicity of the nineteenth and twentieth centuries after Kondorskaya and Shebalin [1977], shown as pink and red circles, respectively, scaled by magnitude. Inset shows earthquakes of $M s$ $>7$ (stars). Black dashed box shows inset area. Major NW-SE trending right-lateral strike-slip faults within the mountains: $\mathrm{TF}=$ Talas-Fergana fault, $\mathrm{Dz}=$ Dzhungarian fault. NW-SE Paleozoic Platform faults from $\mathrm{SW}$ to $\mathrm{NE}: \mathrm{Kt}=$ Karatau fault, $\mathrm{Dh}=$ Dzhalair-Naiman fault, $\mathrm{Ak}=\mathrm{Aktas}$ fault, and $\mathrm{Ch}=$ Chingiz fault [Tapponnier and Molnar, 1979]. Earthquakes outlined in yellow, with dates, are referred to in the text. 


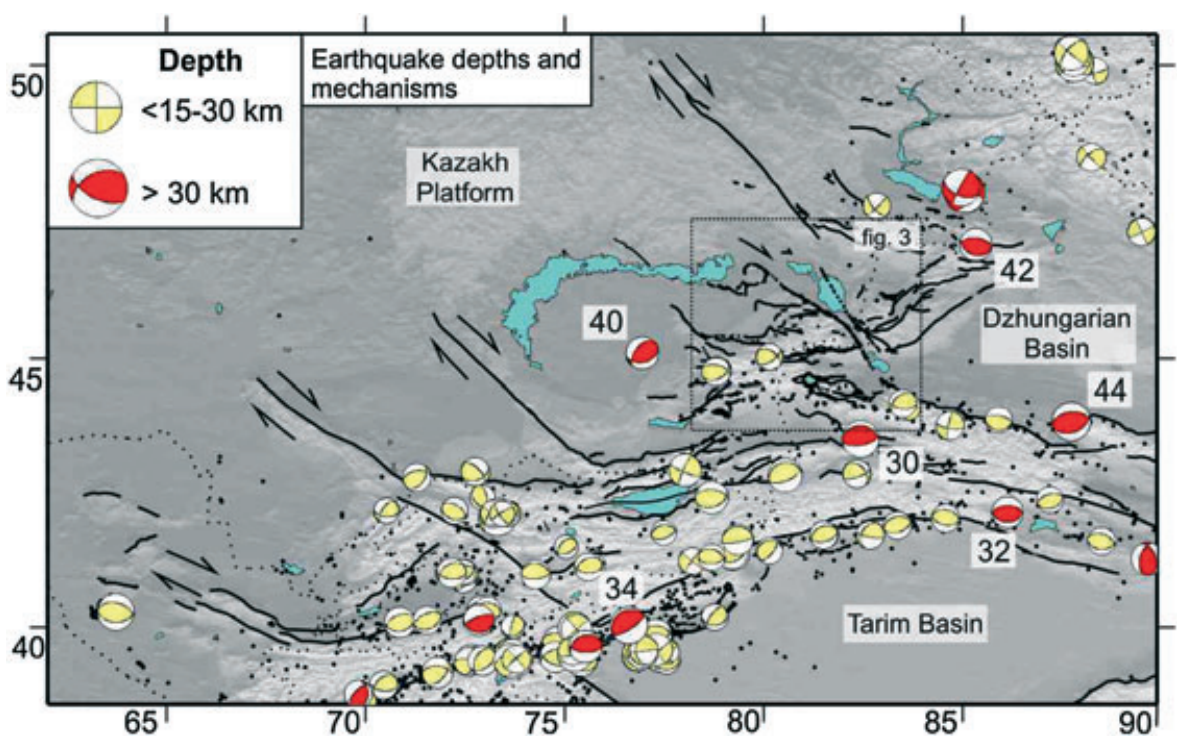

Figure 2. Centroid depths and fault plane solutions for the Tien Shan and its forelands. All earthquake depths are constrained by body wave inversion $(M w \geq 5)$ and are shown as yellow (15-30 km), red ( $\geq 30$ $\mathrm{km}$ ) with locations of the Engdahl et al. [1998] catalog used. The deepest events, with centroids $\geq 30 \mathrm{~km}$, are labeled with depths. Engdahl catalog earthquakes $M w \geq 3$ are shown as black dots. Modeled earthquake depths and fault plane solutions are from Sloan et al. [2011] and references therein.

motion across the fault [Zubovich et al., 2010; Molnar and Dayem, 2010; Mohadjer et al., 2010]. This paper presents new information on the less well known NW-SE right-lateral Dzhungarian fault [Voitovich, 1969], which extends over $300 \mathrm{~km}$ from the western end of the Dzhungarian Basin $\left(44^{\circ} 07^{\prime} \mathrm{N}, 83^{\circ} 41^{\prime} \mathrm{E}\right)$ in NW China, to the eastern tip of Lake Balkhash $\left(47^{\circ} 08^{\prime} \mathrm{N}, 78^{\circ} 43^{\prime} \mathrm{E}\right)$ in Kazakhstan (Figures 3 and 4). The slip rate of this major fault remains unclear, with existing estimates relying on the assumptions of displaced landforms or from extrapolations of geodetic or chronological data. Shen et al. [2003] estimated a slip rate of $\sim 5 \mathrm{~mm} / \mathrm{yr}$ at the southern end of the Dzungarian fault from the assumed age of an alluvial fan displaced by $\sim 50 \mathrm{~m}$, whereas England and Molnar [1997] estimate a slip rate of $\sim 3 \pm 1 \mathrm{~mm} / \mathrm{yr}$ using GPS velocity measurements and the accumulation of 7 $\mathrm{km}$ right-lateral offset since the Pliocene [Voitovich, 1969].

[5] We first discuss the general characteristics of the Dzhungarian fault in its regional tectonic and geological context and what is known about the earthquake history. We then characterize the geomorphological features of the fault from field-based and satellite observations and use optically stimulated luminescence (OSL) dating methods to derive the first quantitative estimate of its late Quaternary slip rate. Finally, we discuss the role of the Dzhungarian fault in accommodating the northernmost tectonic strain related to the ongoing India-Eurasia collision and the potential seismic hazard it poses.

\section{The Northern Tien Shan: Geology, Seismicity, and Late Cenozoic Tectonics}

\subsection{Geology}

[6] The Tien Shan extends east-west for $2500 \mathrm{~km}$ and covers parts of Kyrgyzstan, Kazakhstan, Tajikistan, and northwest China. Bounded by the Kazakh Platform in the north and the stable Tarim Basin in the south (Figure 1), the Tien Shan is one of the most seismically active intracontinental mountain belts in the world, with deformation related to the Eocene-present IndiaEurasia collision.

[7] The mountains consist of a series of east-west oriented, fault-bounded ranges or massifs separated by Late Cenozoic sedimentary basins and are formed mostly from amalgamated island arc terranes which date from the Palaeozoic [Burtman, 1975]. Local relief is several kilometers with adjacent intermontane basins containing up to 10 $\mathrm{km}$ of Cenozoic sediment [Hendrix et al., 1992]. Regionally extensive peneplain surfaces are often preserved at mountain summits, suggesting that there was little regional relief prior to the Late Cenozoic reactivation [Abdrakhmatov et al., 2001; Korjenkov et al., 2007; Oskin and Burbank, 2007], which followed several earlier episodes of mountain building [Windley et al., 1990; Glorie et al., 2010]. The most recent phase of mountain building initiated $\sim 25 \mathrm{Ma}$ ago in the western and central Tien Shan, a date inferred from apatite and detrital fission-track data and from magnetostratigraphic studies from the Kyrgyz Range [Sobel et al., 2006; De Grave et al., 2007; Bullen et al., 2001, 2003].

\subsection{Seismicity and Rates of Shortening}

[8] GPS measurements show that the current shortening rate of $\sim 20 \mathrm{~mm} / \mathrm{yr}$ across the Tien Shan is nearly half that of India's convergence rate with Eurasia [DeMets et al., 1990; Abdrakhmatov et al., 1996; Reigber et al., 2001b; Yang et al., 2008; Zubovich et al., 2010]. Shortening is fastest in the western Tien Shan, consistent with the clockwise rotation of the Tarim basin relative to stable Eurasia about an axis in North-Eastern Tibet [Avouac et al., 1993; Reigber et al., 2001a; Shen et al., 2001]. In contrast to the fast rates of shortening observed N-S across the Tien Shan, GPS measurements show very low, though significant 


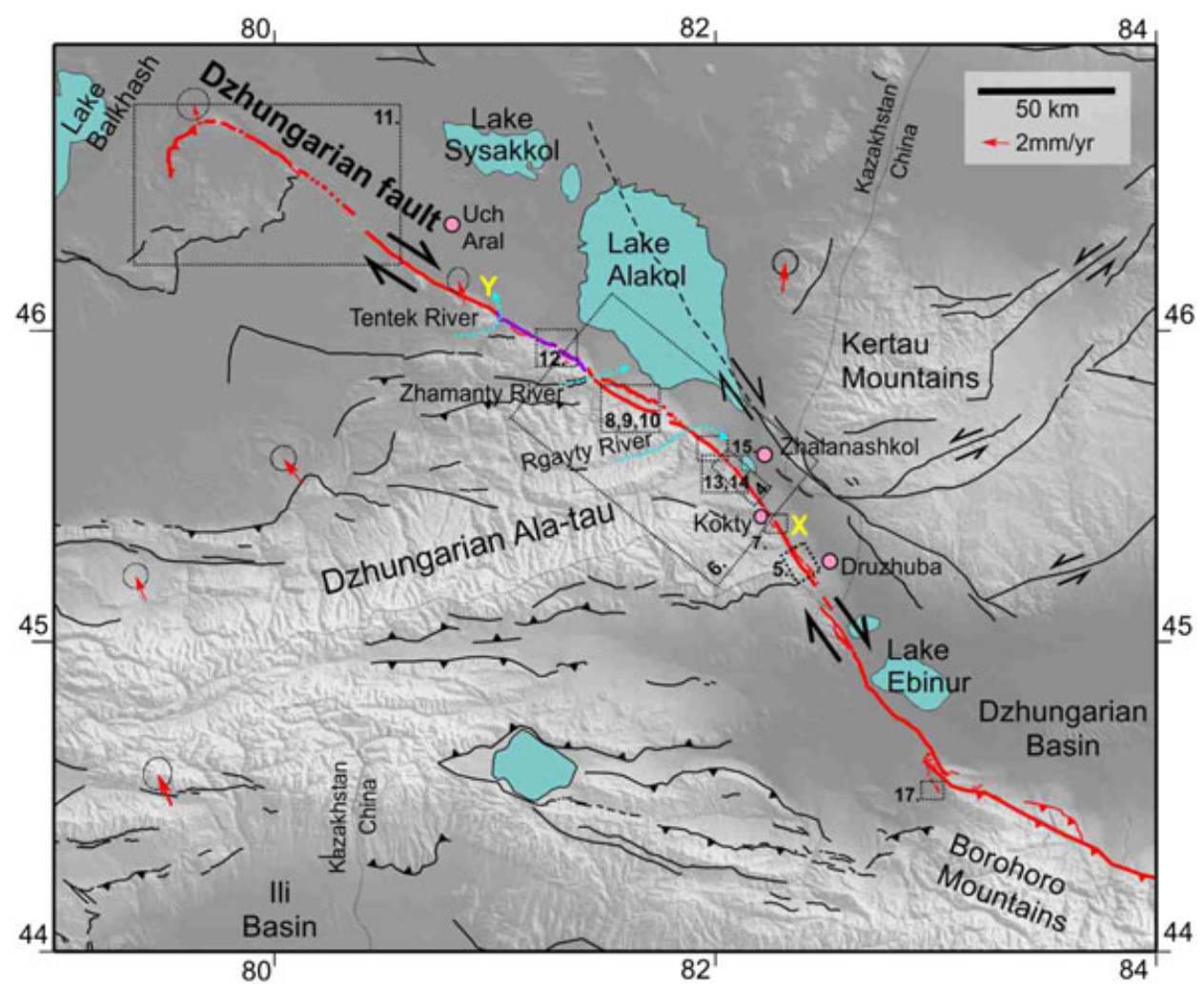

Figure 3. The Dzhungarian fault and other active faults of the Dzhungarian Ala-tau and northern Tien Shan region determined from field and remote sensing data observations of this study and literature [Tapponnier and Molnar, 1979; Thomas et al., 1996; Abdrakhmatov et al., 2002; Buslov et al., 2003; Buckman and Aitchison, 2004; Trifonov, 2004]. Points X and Y denote $\sim 160 \mathrm{~km}$ surveyed in the field. Purple line is a $32 \mathrm{~km}$ long possible paleo-earthquake rupture (see section 4). Black dashed boxes and numbers correspond to other figure locations in this paper. Available GPS velocity data for this region are also plotted from Zubovich et al. [2010] and are relative to stable Eurasia. Towns are marked with pale red circles.

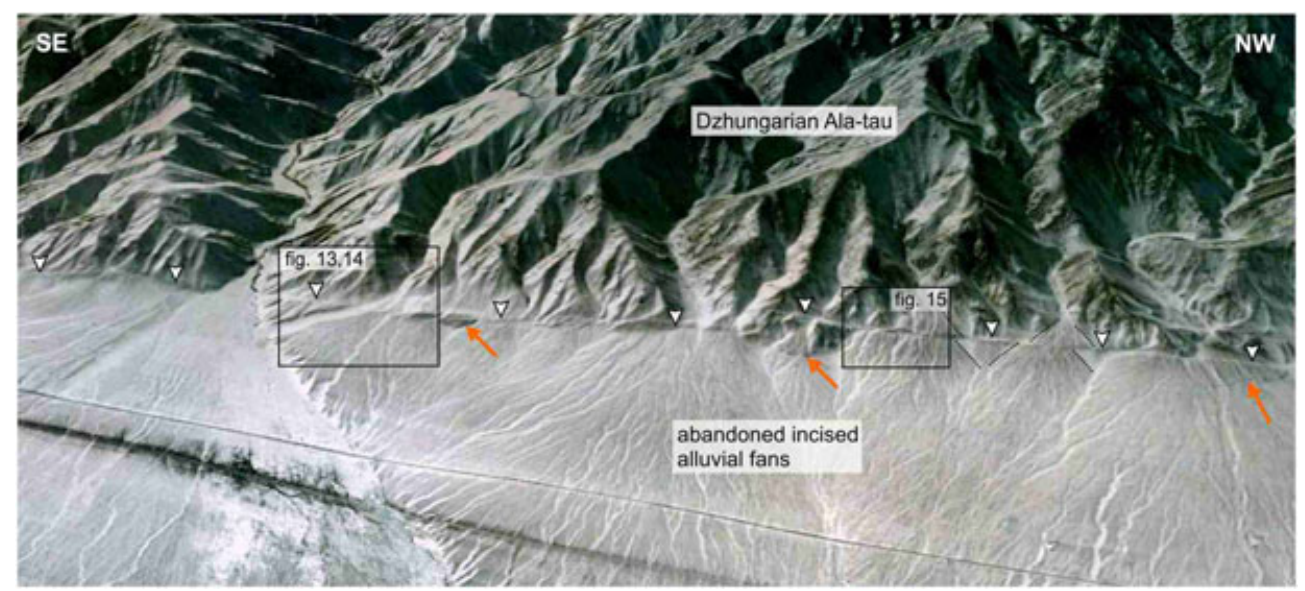

Figure 4. Satellite image (source: http://earth.google.com) showing the central section of the Dzhungarian fault centered at $45^{\circ} 35^{\prime} \mathrm{N}, 82^{\circ} 02^{\prime} \mathrm{E}$, the fault trace at the base of the range front is marked by white triangles. The strike-slip component can be observed right laterally offsetting small channels (shown within black boxes) and beheading alluvial fans (dashed black lines delimit fan edges which have been displaced). Orange arrows indicate small-scale reversals in the local topography due to fault segmentation. 
strain rates $\left(10^{-16} \mathrm{~s}^{-1}\right)$ [Zubovich et al., 2010] within the Kazakh Platform.

[9] Earthquake fault plane solutions across the Tien Shan region show a majority of E-W trending thrust faults, with relatively fewer strike-slip events (Figure 2). Thompson et al. [2002] use a variety of dating methods on faulted and folded river terraces and from trenches to reveal geological evidence for active thrust faulting with late Quaternary slip rates of 0.1 to $3.0 \mathrm{~mm} / \mathrm{yr}$ across several subranges of the central Tien Shan. They show that shortening is therefore likely to be distributed N-S throughout the mountains, rather than concentrated at the major north and south boundaries.

\subsection{Historical and Modern Earthquakes}

[10] The most famous historical earthquakes of the northern Tien Shan are those that have been destructive during the late nineteenth and early twentieth centuries (Figure 1b). A series of destructive earthquakes began with the 1885 M 6.9 Byelovoda earthquake [Molnar and Ghose, 2000], which has been associated with the north facing range-front fault of the Kyrgyz Range, $\sim 50 \mathrm{~km}$ west of Bishkek; this was followed by the $1887 M 7.3$ Verny earthquake [Mushketov, 1890; Hay, 1888], also thought to be associated with the north slope of the Tien Shan, south of Almaty (formerly Verny) [Molnar and Ghose, 2000]. These events were followed by the larger magnitude $1889 M 8.3$ Chilik [Mushketov and Survorin, 1891] and the $1911 \mathrm{Ms}$ 8.2 Kemin events [Bogdanovich et al., 1914] (Figure 1b), both of which have been linked to the E-W trending, left-lateral Chon-Kemin-Chilik fault zone, located between the Issyk-Kul Basin and the Kazakh Platform (Figure 1b inset). The Chon-Kemin, Chilik, and Chon-Aksu fault segments separate the Kungey Mountains in the south from the Zailiskey Range to the north [Bogdanovich et al., 1914; Delvaux et al., 2001; Selander et al., 2012] (Figure 1b, inset). The 1911 Chon-Kemin event apparently activated several different fault segments of this fault zone, resulting in a complex combination of reverse and left-lateral strikeslip motion with an average slip of $4 \mathrm{~m}( \pm 1.5 \mathrm{~m})$ and over $188 \mathrm{~km}$ of observed surface ruptures [Bogdanovich et al., 1914; Kuchay, 1969; Molnar and Ghose, 2000].

[11] The only potential candidate for a historic large magnitude earthquake on the long NW-SE right-lateral strike-slip faults is the $1946 M 7.6$ Chatkal earthquake, which has been linked to the range-interior Talas-Fergana fault; however, the estimated epicenter of this earthquake is $\sim 25 \mathrm{~km}$ southwest of the Talas-Fergana fault and there remains no evidence of a surface rupture relating to this event [Simpson and Hamburger, 1981]. There is no historical record of large magnitude earthquakes on the Dzhungarian fault. It is likely that large magnitude earthquake repeat times on these long NW-SE faults are longer (e.g., thousands of years) than is represented by the 200 year historical record and, although erosion rates are very low, the most recent surface-rupturing earthquakes may be older than can be preserved clearly in the landscape. However, as discussed, both the strike-slip and range-front thrust faults of the northern Tien Shan can generate large magnitude, potentially destructive earthquakes; so the presence, and possible interaction of these faults, has important hazard implications for major cities such as Almaty and Bishkek, which are close to both types of fault (Figure 1a).

\section{The Dzhungarian Fault}

[12] The Dzhungarian fault (Figures 3 and 4) extends for over $300 \mathrm{~km}$ from the western end of the Dzhungarian Basin $\left(44^{\circ} 07^{\prime} \mathrm{N}, 83^{\circ} 41^{\prime} \mathrm{E}\right)$ in NW China, to the eastern tip of Lake Balkhash $\left(47^{\circ} 08^{\prime} \mathrm{N}, 78^{\circ} 43^{\prime} \mathrm{E}\right)$ in Kazakhstan. In its central section, the fault bounds $150 \mathrm{~km}$ of the eastern extent of the Dzhungarian Ala-tau, forming a narrow tectonic mountain pass between the Dzhungarian Ala-tau of Kazakhstan and the Kertau of western China. This mountain corridor, known as the Dzhungarian Gates, is bounded by faults on both sides [Tapponnier and Molnar, 1979] and contains Alakol and several other smaller internally drained lakes.

[13] We present detailed field observations along $\sim 160 \mathrm{~km}$ of the Dzhungarian fault (between points $\mathrm{X}$ and Y, Figure 3), from Lake Alakol in the south, to Uch Aral in the north, describing first the structure and geomorphology, and then evidence for a possible paleo-earthquake rupture. Finally, we present an estimate of late Quaternary slip rate on the fault, based upon offset channels in alluvial fans dated using optically stimulated luminescence (OSL).

\subsection{Fault Structure and Geomorphology}

[14] Observations of the structure and geomorphology along the Dzhungarian fault indicate that there are three characteristic, $\sim 100 \mathrm{~km}$ long fault sections: SE, central, and NW, which we discuss below.

\subsubsection{Southeast: Lake Ebinur}

[15] In the SE, remote observations of satellite imagery indicate that the main NW-SE trending Dzhungarian fault joins with the ESE-WNW trending Borohoro Mountains of NW China (Figure 3). Further north, the fault tracks west of Lake Ebinur through late Quaternary alluvium and is associated with very little relief. Where the SE Dzhungarian Ala-tau begin $\left(\sim 45^{\circ} 10^{\prime} \mathrm{N}, 82^{\circ} 27^{\prime} \mathrm{E}\right)$, the main strike-slip fault is observed at the base of the low range front (Figures 3 and 5). Small channels exit the mountains and incise abandoned fan deposits, which have been raised by reverse slip on a second strand of the main fault (Figure 5). The channels show apparent right-lateral displacement where they cross the main fault. This configuration of faulting is suggestive of "partitioning" of strike-slip and reverse components of motion onto separate subparallel strands with orthogonal slip vectors. In the SE section of the Dzhungarian fault, this slip partitioning is only a local feature, $\sim 15 \mathrm{~km}$ long, caused by a slight restraining bend in the main fault trace.

[16] Continuing north to a latitude of $\sim 45^{\circ} 26^{\prime} \mathrm{N}, 82^{\circ} 12^{\prime} \mathrm{E}$, field observations reveal a series of along-strike infilled tension fissures (Figure 6 inset) and push-up structures preserved in late Quaternary deposits, indicating that the main fault is sited several kilometers northeast of the range front and is almost pure strike-slip. Through this SE section ( $\sim 110 \mathrm{~km}$ length), the fault trends $\sim 340^{\circ}$, parallel to the orientation of NNW-SSE shortening across the Dzhungarian Ala-tau as determined by GPS measurements (Figure 3) [Zubovich et al., 2010].

\subsubsection{Central: Lake Alakol}

[17] North of Druzhuba (Figure 3), where relief begins to increase, the main trace of the fault joins the base of the Dzhungarian Ala-tau range front. Along-strike push-up structures and infilled sag ponds (Figure 7) are preserved 


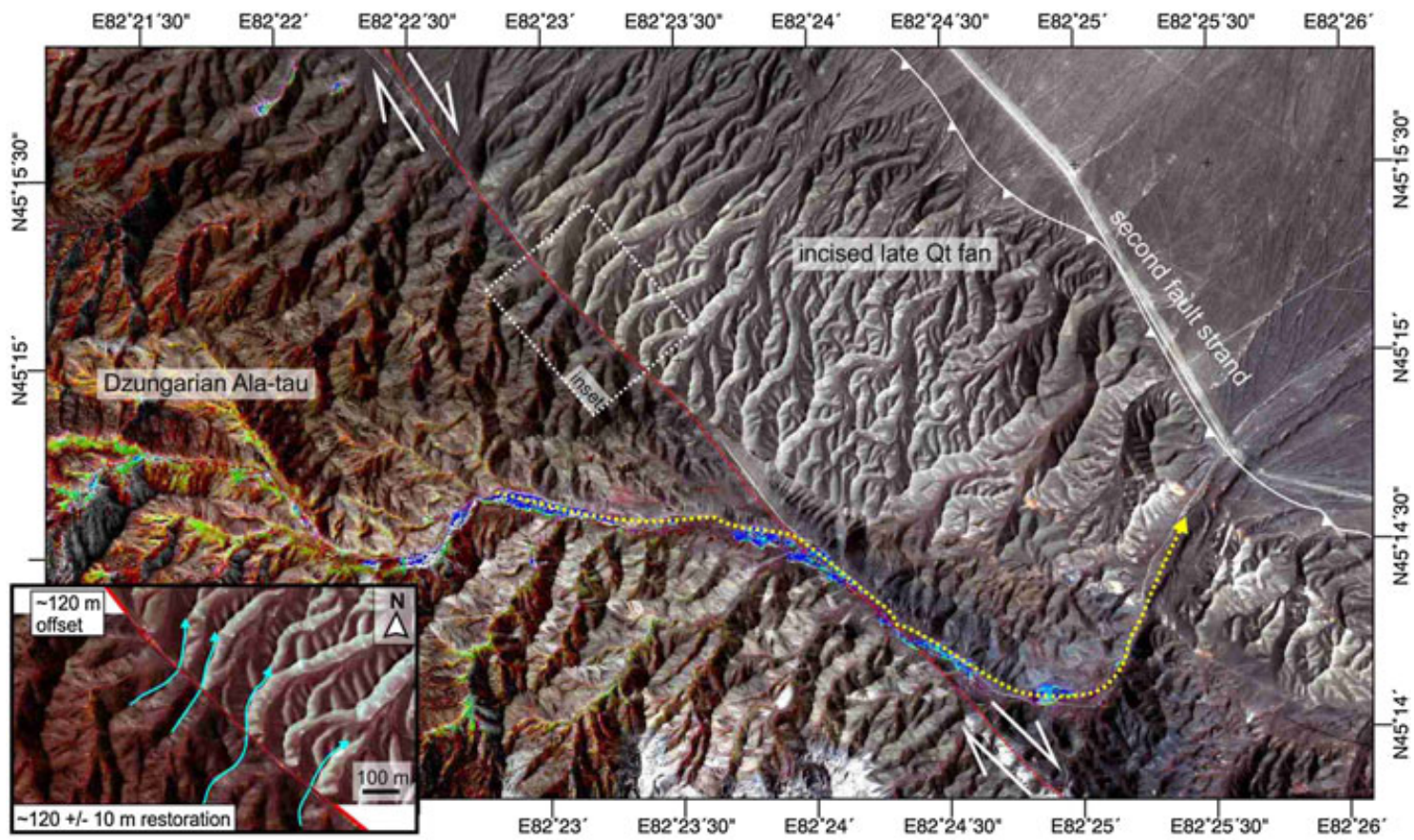

Figure 5. A $1 \mathrm{~m}$ pixel Kompsat-2 image of the SE section of the Dzhungarian fault, $\sim 50 \mathrm{~km} \mathrm{NW}$ of Lake Ebinur (see Figure 3 for regional location). The main trace of the Dzhungarian fault, which trends $\sim 340^{\circ}$ through this SE section of the fault is marked by a red dotted line. Channels exit the Dzhungarian Ala-tau and drain NE and actively incise abandoned; late Quaternary alluvial fan surfaces. The white dashed box denotes the area of the inset, which shows two prominent channels that have been offset right laterally by $\sim 120 \mathrm{~m}$ as they cross the main trace of the fault. The inset shows that a geomorphic restoration of $\sim 120 \mathrm{~m}$ of right-lateral slip will restore beheaded channels (blue arrows) into alignment $\mathrm{NE}$ and SW of the Dzhungarian fault. A second fault strand $(\sim 2 \mathrm{~km} \mathrm{NE}$ of the main fault trace, marked with a white line) uplifts the abandoned alluvial fan to the NE which is subsequently incised by channels. A major river channel (yellow dotted line) shows a greater cumulative right-lateral offset of $\sim 1.4 \mathrm{~km}$.

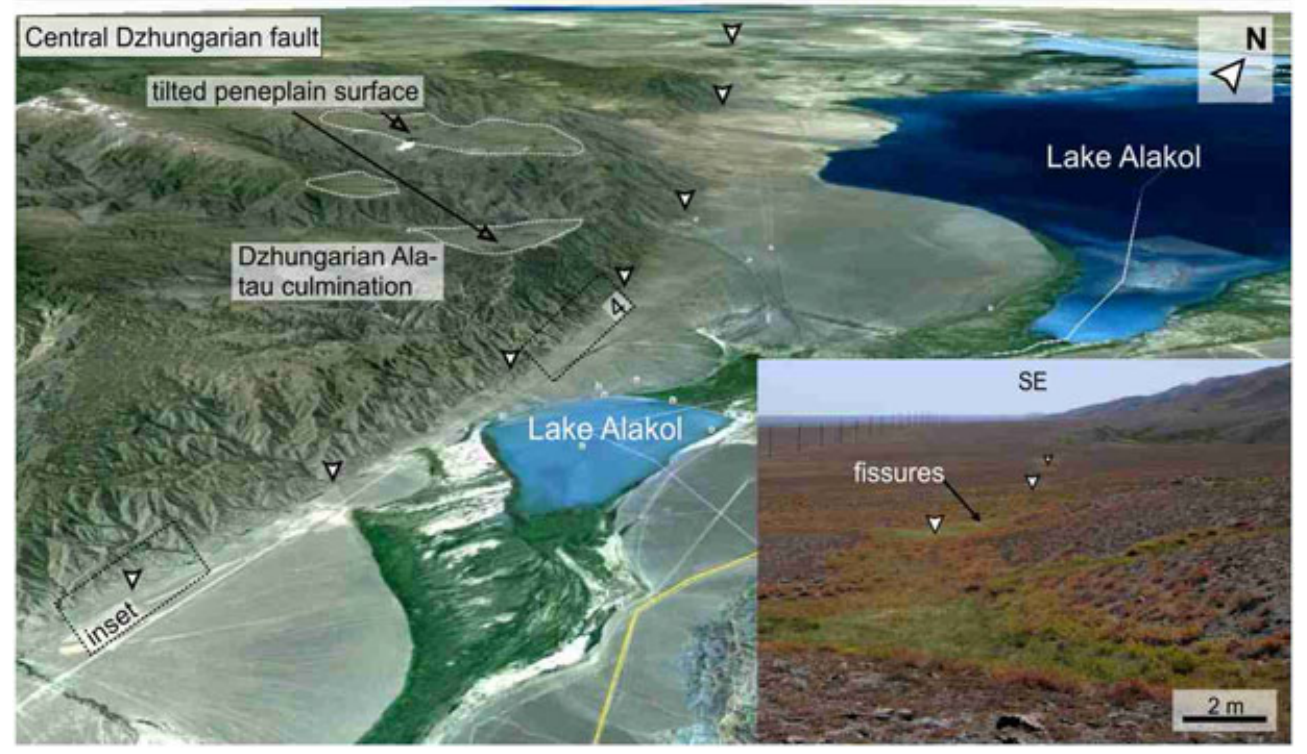

Figure 6. (a) Satellite image (source: http://earth.google.com) showing the $\sim 25^{\circ}$ change in fault strike opposite Lake Alakol, where there is a culmination in the elevation of the Dzhungarian Ala-tau. The peneplain surface is also denoted in white dotted lines; the inset field photo (taken at $45^{\circ} 26^{\prime} \mathrm{N}, 82^{\circ} 13^{\prime} \mathrm{E}$ ) shows the fault preserved as infilled tension fissures several hundreds of meters NE of the range front, $\sim 10 \mathrm{~km} \mathrm{NW}$ of Kokty. 


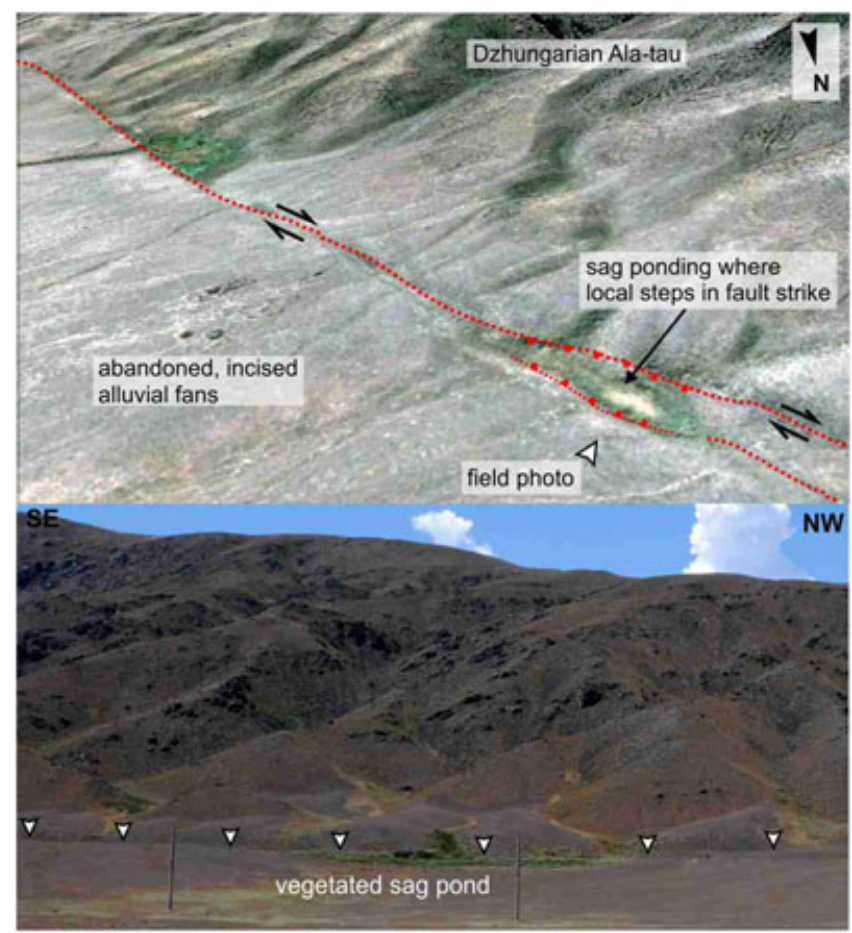

Figure 7. Satellite image (source: http://earth.google.com) looking SE along the SE section of the Dzhungarian fault. Where there are local changes in the strike of the fault, push-up mounds and now infilled sag ponds have formed against the scarp. Field photo of the SE Dzhungarian fault looking west from $45^{\circ} 31^{\prime}, 82^{\circ} 07^{\prime} \mathrm{E}$, the main fault follows the base of the range front and a vegetated sag pond has formed where there is a small step in the fault.

in late Quaternary deposits associated with local changes in strike along the main trace of the Dzhungarian fault.

[18] Continuing north to $\sim 45^{\circ} 41^{\prime} \mathrm{N}, 81^{\circ} 44^{\prime} \mathrm{E}$, the Dzhungarian Ala-tau reaches a maximum relief of $\sim 2000 \mathrm{~m}$ above the surrounding alluvial plains, at a point coinciding with a $\sim 25^{\circ}$ (from $\sim 340^{\circ}$ to $\sim 315^{\circ}$ ) change in overall strike of the fault near Lake Alakol (Figures 3 and 6). Along this central section of the fault, the SW side is uplifted. We infer that the uplift is from a reverse slip component, which is manifested in NE facing scarps in late Quaternary material $\sim 4 \mathrm{~km} \mathrm{NE}$ of the range front (Figures $8 \mathrm{a}-8 \mathrm{c}$ ). Older alluvial fans are higher and dissected by lower younger surfaces draining to the local base level at Lake Alakol (Figures $8 \mathrm{a}-$ 8c). The total relief at this culmination point is not likely to be due to the Dzhungarian fault alone, which only shows a reverse component where there are local departures in the strike of the fault from the $\sim 340^{\circ}$ "pure strike-slip" direction, but it is at least influenced by the Dzhungarian fault. The Dzhungarian Ala-tau are formed of a series of E-W trending mountain ridges that are truncated at their eastern extent by the NW-SE Dzhungarian strike-slip fault. It is likely that the majority of relief formed and evolved along the range-interior E-W thrust faults during earlier periods of mountain building.

[19] Between the Rgayty gorge and Zhamaty river (Figure 3), a second fault strand, parallel to the range-front fault described above, continues through the mountains for $\sim 25 \mathrm{~km}$ (Figure 9). Interfluvial ridges and channels are displaced right laterally across this second fault by $35 \pm$ $5 \mathrm{~m}$ (Figures $9 \mathrm{a}-9 \mathrm{c}$ ). Through this $\sim 25 \mathrm{~km}$ section, the configuration of faulting is again suggestive of slip partitioning. We observe this fault configuration where there are local changes in fault strike. In most places along this central section there is a clear fault within the steepest mountain topography and a lower, more subdued fault closer to the adjacent basin, often associated with low elongate ridges of folded and tilted sediments (Figure 10), resembling the "forebergs" described by Florensov and Solonenko [1963], Baljinnyam et al. [1993], and Bayasgalan et al. [1999b] in the Gobi-Altai of Mongolia.

[20] Between the Zhamanty and Tentek Rivers (Figure 3), the elevation of the Dzhungarian Ala-tau decays from $\sim 2300$ to $\sim 800 \mathrm{~m}$. This decrease in relief correlates with remote satellite observations that indicate that the main Dzhungarian fault may become segmented and branch successively westwards into the mountains, with the distribution of slip across several fault segments leading to a decay in relief on approach to the Tentek River. In the field, we observe a possible paleo-earthquake rupture preserved within abandoned alluvial fans along the base of the high steep range front (discussed below, section 4).

\subsubsection{Northwest Dzhungarian: Lake Sasyqkol}

[21] Northwest of the Tentek River (Figure 3), the Dzhungarian fault cuts through relatively low topography, with mountain elevation just NW of the Tentek River reaching a maximum of $1000 \mathrm{~m}$ a.s.l and the decay of average relief northwestward (to $\leq 100 \mathrm{~m}$ ). Through this NW section, the Dzhungarian fault strikes $\sim 315^{\circ}$ and is marked by a continuous, degraded $5 \mathrm{~m}$ high scarp in late Quaternary vegetated alluvial surfaces. There is little evi- 

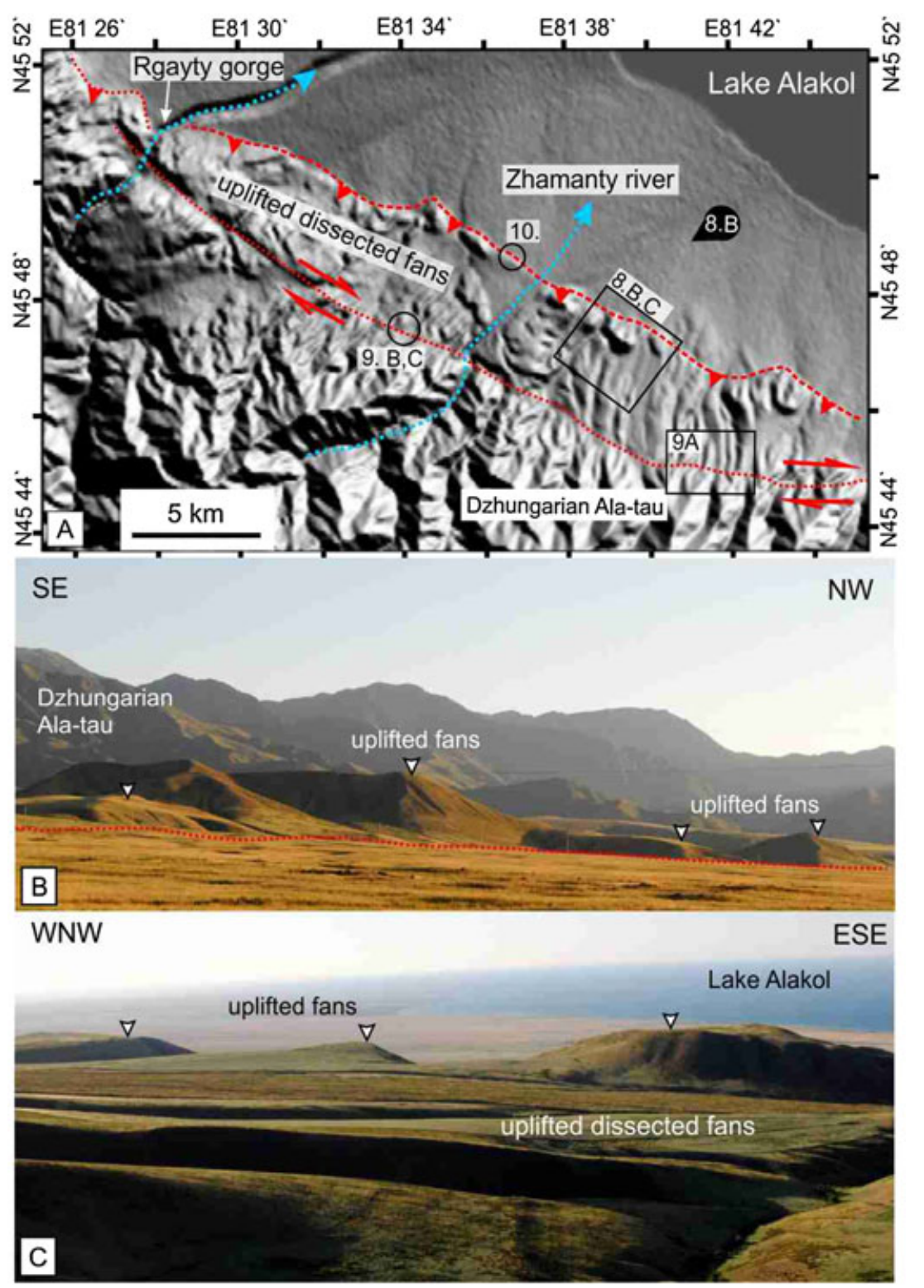

Figure 8. Slip partitioning along the central section of the Dzhungarian fault. See Figure 3 for regional image location. (a) A $90 \mathrm{~m}$ pixel resolution Shuttle Radar Topography Mission (SRTM) sun-shaded DEM data of the central section of the Dzhungarian fault near lake Alakol. (b, c) Field photos from $45^{\circ} 45^{\prime} \mathrm{N}$, $81^{\circ} 42^{\prime} \mathrm{E}$, of uplifted, incised late Quaternary alluvial fans through the central section of the Dzhungarian fault. The reverse component is greater through this central section of the fault, relative to the NW and SE sections, and is introduced on a lower, secondary strand of the fault as the fault strike changes $\sim 25^{\circ}$. Fans preserve $\sim 10 \mathrm{~m}$ cumulative uplift. The main strike-slip component remains against the steeper range front and is shown as a red dotted line in Figure 8a whereas the reverse component of shortening is accommodated on the lower secondary fault strand (red dashed line with teeth). This fault configuration is typical of strain partitioning (see section).

dence of fault segmentation or slip partitioning NW of the Tentek River. The subdued geomorphology through the NW fault section, relative to that observed in the central and SE fault sections, may result from along-strike variation of the fault slip rate.

[22] At its north-westernmost extent, satellite imagery and digital elevation data suggest that the Dzhungarian fault terminates abruptly against an orthogonal fault trending NE-SW along which vertical offset decays away from the main trace of the Dzhungarian fault (Figures 3 and
11). Such orthogonal fault terminations have been described from other intraplate strike-slip faults, for example, in the Mongolian Gobi-Altai [Bayasgalan et al., 1999a] and Iran [Berberian et al., 2000; Walker et al., 2004; Hollingsworth et al., 2006], where they terminate in orthogonal thrust faults, along which displacement decreases away from the strike-slip fault. Bayasgalan et al. [1999a] suggest this geometry allows strike-slip faults to terminate in plate interiors by rotations about a vertical axis. This observation of fault geometry has implications for the role of the 


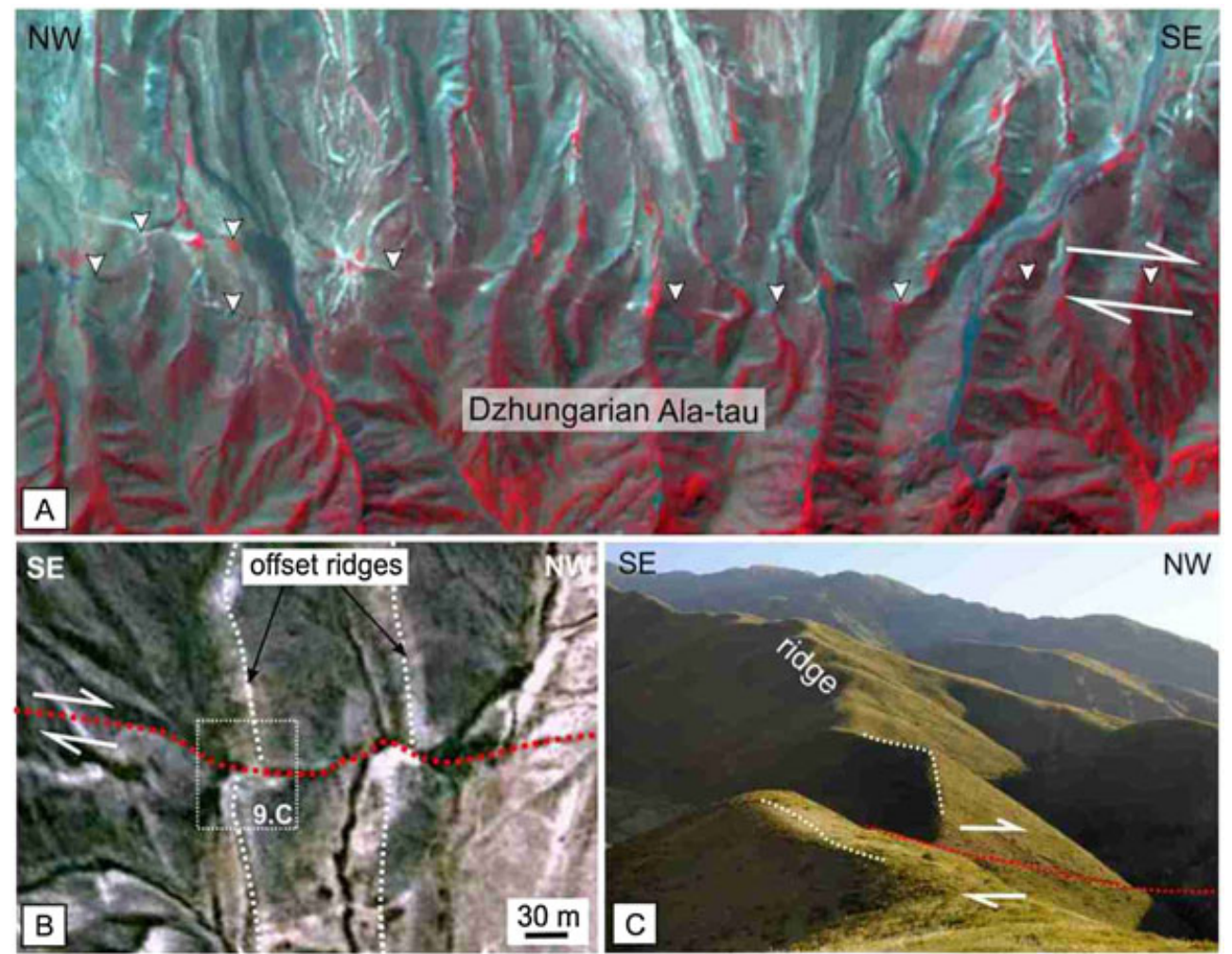

Figure 9. Slip partitioning along the central section of the Dzhungarian fault. (a) False color Advanced Spaceborne Thermal Emission and Reflection Radiometer (ASTER) satellite image (see Figure 8 black box for image location), showing the trace of the main strike-slip fault (marked with white triangles), which cuts through the range front. (b) Satellite image (source: http://earth.google.com) of right laterally displaced interfluvial ridges where the strike-slip component of the Dzhungarian fault continues at the high, steep range front. (c) Field photo from $45^{\circ} 44^{\prime} \mathrm{N}, 81^{\circ} 43^{\prime} \mathrm{E}$, of the same displaced ridges in 9.B displacement $=35 \pm 5 \mathrm{~m}$.

Dzhungarian strike-slip fault in accommodating overall N-S convergence (see section 6.2).

\section{Possible Paleo-Earthquake Rupture}

[23] The only definitive paleo-earthquake rupture we observed in the field was along a shorter fault strand of the segmented central section of the Dzhungarian fault. We interpret it to be a single earthquake rupture because we can observe a clear beginning and end and it is fresher in appearance in both the satellite imagery (Figure 12a) and in the field (Figure 12b) than any other section along the fault. The possible rupture is a continuous $\sim 1.6 \mathrm{~m}$ scarp preserved within abandoned alluvial fans (Figure 12) NE of the high steep range front between $45^{\circ} 59^{\prime} \mathrm{N}, 81^{\circ} 08^{\prime} \mathrm{E}$ and $45^{\circ} 50^{\prime} \mathrm{N}, 81^{\circ} 29^{\prime} \mathrm{E}$ (see Figure 3 between the Tentek River and south of Zhamaty River gorge). We followed this rupture from $45^{\circ} 59^{\prime} \mathrm{N}, 81^{\circ} 08^{\prime} \mathrm{E} \sim 32 \mathrm{~km}$ south to the Zhamaty River gorge, where it ends. We note that we did not examine the strike-slip fault in the higher mountains north of the Rgayty River in detail in the field; therefore, we cannot confirm whether or not it also displays paleo-earthquake ruptures.

[24] Along the observed rupture, we discern no rightlateral displacements, suggesting that this event accommodated the partitioned reverse component of overall N-S shortening, which is likely to be associated with the formation of the foreberg structures also observed along the central section of the Dzhungarian fault (Figure 10). This

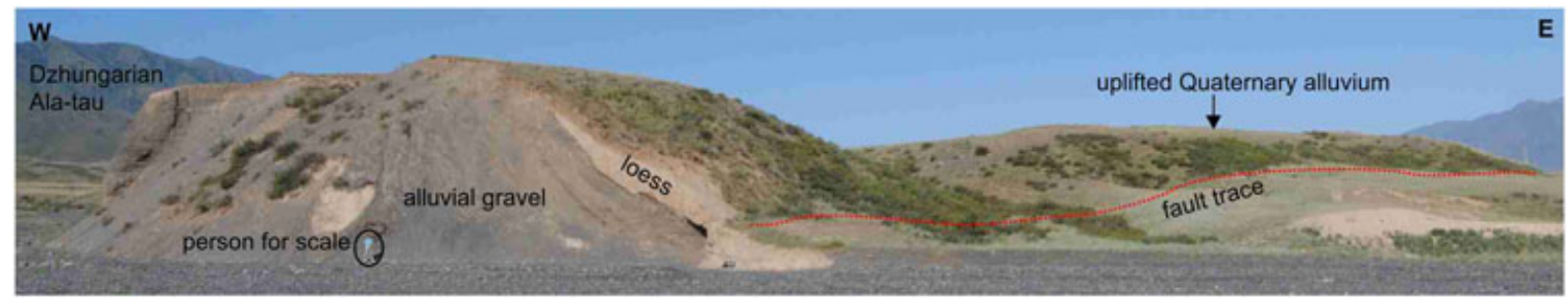

Figure 10. Field photo of a "foreberg" structure at $45^{\circ} 48^{\prime} \mathrm{N}, 81^{\circ} 37^{\prime} \mathrm{E}$, a low, elongated ridge of uplifted, tilted, and deformed sediments, uplifted by a reverse component on a lower segment of the main fault, $\sim 2 \mathrm{~km}$ E of the range front. The tilted sediments are cut by small reverse faults. 


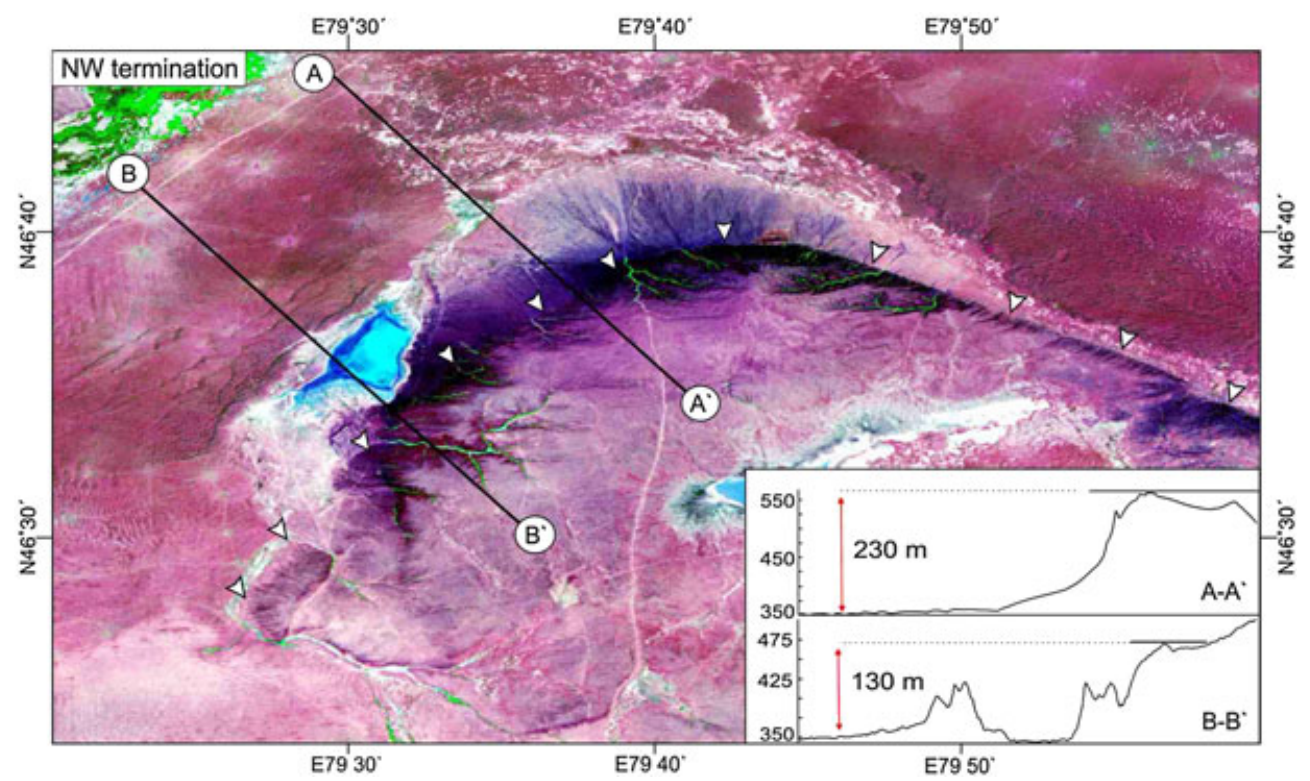

Figure 11. Landsat satellite image of the NW Dzhungarian fault. The fault (marked with white triangles) possibly terminates in an orthogonal, NE-SW, thrust fault. Elevation profiles normal to the strike of the NE-SW thrust fault are shown in the bottom right inset and indicate that vertical offset decays away from the main strike-slip fault $(230$ to $130 \mathrm{~m})$. This faulting configuration is observed in Mongolia [Bayasgalan et al., 1999a], where strike-slip faults possibly rotate about a vertical axis as a mechanism for terminating within continent interiors. See "Discussion" (section 6.1).

observation indicates that despite being $\sim 300 \mathrm{~km}$ in length, the Dzhungarian fault may rupture in shorter segments that are associated with slip partitioning of strike slip and reverse components of shortening.

[25] With this in mind, if the ratio of slip to rupture length $(\bar{u} / L)$ in earthquakes has a typical value of $\sim 5 \times 10^{-5}$ [Scholz, 1982], and if the total $\sim 32 \mathrm{~km}$ rupture between the Tentek river and Zhamaty river gorge was generated in a single earthquake, the expected average amount of slip on this frontal fault plane would be $\sim 1.6 \mathrm{~m}$. This is roughly consistent with the calculated slip of $2.3 \mathrm{~m}$ for a fault dipping $45^{\circ}$ with a vertical displacement of $1.6 \mathrm{~m}$. From the relationship $M_{0}=\mu A \bar{u}$, we estimate a moment $M_{0}$ of $\sim 4.4 \times 10^{19} \mathrm{Nm}$ for an earthquake rupturing the entire $32 \mathrm{~km}$ length of the fault along this section, to a depth of $\sim 20 \mathrm{~km}$, and at a dip of $45^{\circ}$. For this estimate, we have assumed a value of $3 \times 10^{10} \mathrm{Nm}^{-2}$ for the shear modulus $(\mu)$ and a typical depth of earthquakes in the central Tien Shan (Figure 2). Our estimate yields a moment magnitude $M_{w}$ of $\sim 7$.

[26] If, however, we consider a rupture length of $100 \mathrm{~km}$, for example, an earthquake rupturing the unsegmented SE or NW sections of the Dzhungarian fault, and assuming a value for the seismogenic thickness of $20 \mathrm{~km}$, the scaling relationships yield $\bar{u}$ of $5 \mathrm{~m}$ and a moment magnitude of $M_{w}$ 7.6. From Figure 2, there are a number of earthquakes on rangebounding faults with depths $\geq 30 \mathrm{~km}$; with this potential greater seismogenic thickness, it may be possible to generate larger earthquake magnitudes also.

\section{Late Quaternary Slip Rate}

[27] To assess a late Quaternary slip rate, we chose a site where there is no evidence of slip partitioning. The clearest right-lateral strike-slip offsets were observed opposite
Zhalanashkol (Figures 3 and 4), where the Dzhungarian fault displaces a series of abandoned alluvial fans that have been incised by streams as they exit the Dzhungarian Alatau and drain directly ENE toward the local base level at Lake Alakol. We targeted one of these fans, F1, (shown in Figures 13 and 14) for a slip-rate study described below. A $1 \mathrm{~m}$ pixel Kompsat-2 satellite image shows two consecutive channels (Channel X and Channel Y, Figures 13 and 14) that are displaced right laterally as they cross the Dzhungarian fault. The present-day active channels are defined by vegetation, which corresponds to the brighter red pixels in the Kompsat-2 imagery (Figure 13).

\subsection{River Channel Offsets}

[28] Active Channel $\mathrm{X}$ is $\sim 4 \mathrm{~m}$ wide, $\sim 3-4 \mathrm{~m}$ deep and has steep, well preserved banks. The active Channel Y, which has a larger catchment, has incised $\sim 12 \mathrm{~m}$ into the $\mathrm{F} 1$ fan surface and is wider with less well preserved banks. However, a river terrace riser, T1 (Figure 14) incised into the F1 fan surface from an earlier period of incision is very well preserved and records an equivalent amount of right-lateral offset as the banks of Channel X.

[29] The offset Channel $X$ and the F1-T1 riser adjacent to Channel $\mathrm{Y}$ are excellent markers, along which this offset records the amount of late Quaternary fault displacement. To measure the amount of offset across Channel $\mathrm{X}$ and the F1-T1 riser of Channel Y, we constructed a digital elevation model (DEM) using kinematic GPS (Figure 14a) and use the best fit piercing point for each linear feature: the center of active Channel $\mathrm{X}$ and the crest of the F1-T1 riser, where it meets the fault. To estimate the error for each offset, we measure the minimum and maximum deviation from our best piercing point (Figures 14b and 14c). The base of Channel $\mathrm{X}$ is less well defined than the lineation of the $\mathrm{F} 1-\mathrm{T} 1$ riser 


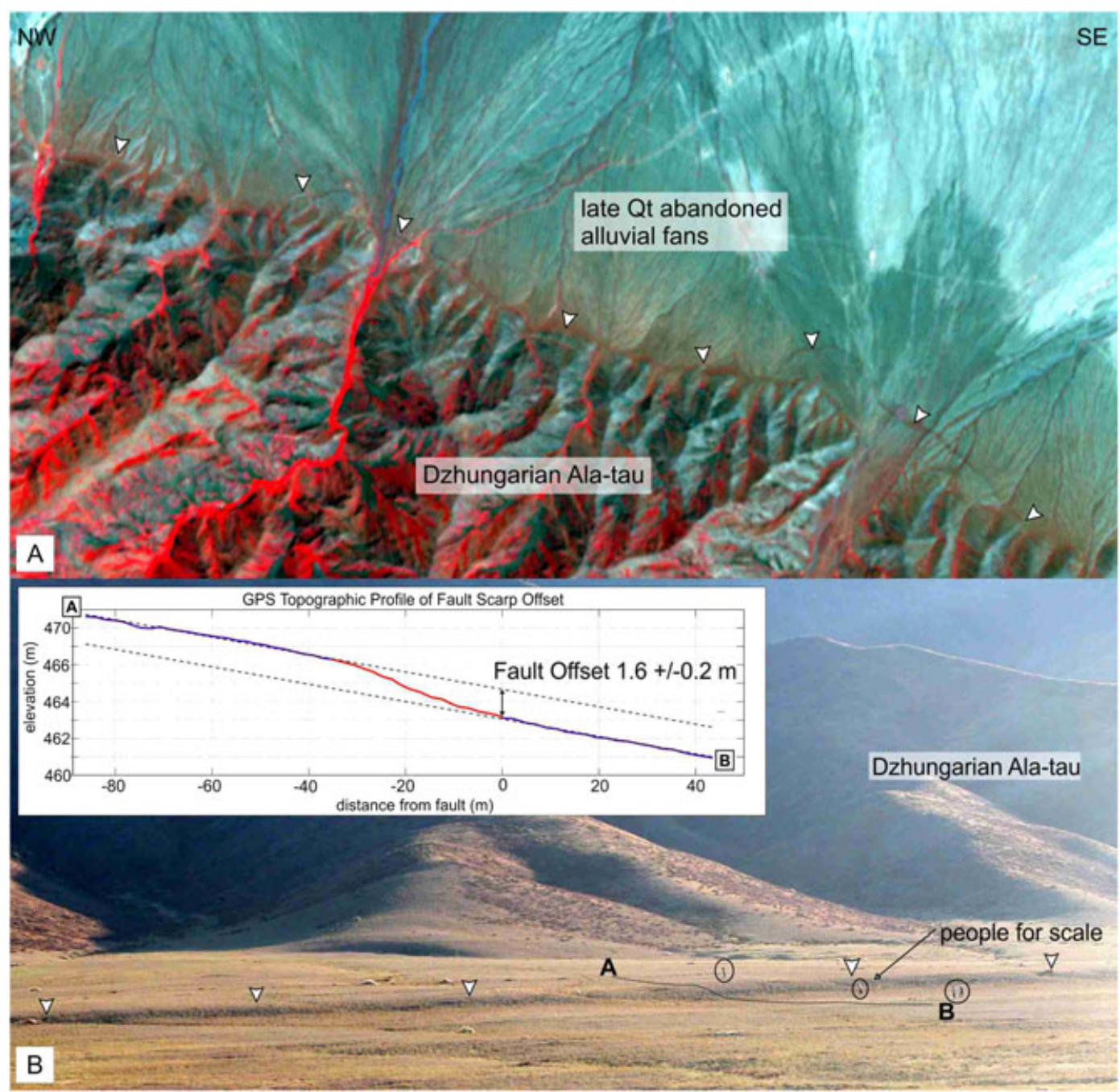

Figure 12. (a) False color ASTER image between $45^{\circ} 55^{\prime} \mathrm{N}, 81^{\circ} 19^{\prime} \mathrm{E}$ and $45^{\circ} 53^{\prime} \mathrm{N}, 81^{\circ} 23^{\prime} \mathrm{E}$ showing the central section of a possible $\sim 32 \mathrm{~km}$ paleo-earthquake rupture preserved in late Quaternary alluvial fans between the Tentek river (in the NW) and the Zhamaty river gorge to the SE. (b) Field photo looking southwest from $45^{\circ} 58^{\prime} \mathrm{N}, 81^{\circ} 11^{\prime} \mathrm{E}$, of the rupture, inset shows a kinematic GPS elevation profile normal to the strike of the rupture, indicating a vertical offset $=\sim 1.6 \mathrm{~m}$.

crest, and the morphology of Channel $\mathrm{X}$ also suggests that it has experienced differential erosion on either side of the fault. We estimate an offset of $53 \pm 7 \mathrm{~m}$ for a piercing point which defines the center point of the Channel $\mathrm{X}$ thalweg and an offset of $54 \pm 4 \mathrm{~m}$ for the piercing point which defines the crest of the $\mathrm{F} 1-\mathrm{T} 1$ riser.

[30] A geomorphological restoration of the same site using $1 \mathrm{~m}$ resolution Kompsat-2 imagery (Figures 13a13c) reveals that restoring $\sim 50 \mathrm{~m}$ of right-lateral slip again realigns the Channel $\mathrm{X}$, Channel Y F1-T1 riser, and also the other incised channels NW and SE of the F1-T1 riser, to their catchments west of the Dzhungarian fault. Along the length of the Dzhungarian fault, we see multiple locations where river channels crossing the fault have recorded the same amount of late Quaternary displacement (Figures 15a-15c), but we also observe less prominent channel offsets that are less than, and greater than, $50 \mathrm{~m}$ (e.g., Figure 17).

\subsection{Luminescence Dating}

[31] Optically stimulated luminescence (OSL) determines the time at which quartz-bearing sediment was last exposed to sunlight. At our slip-rate site in SE Dzhungaria, we find fine-grained quartz-rich fluvial sediment suitable for OSL dating but no organic material for radiocarbon dating methods; we therefore use OSL to date the $\sim 50 \mathrm{~m}$ offset.

[32] We targeted both the abandoned incised fan surface (F1) and the Channel Y river riser terrace (T1) for OSL dating. The age of F1 can be used to estimate a minimum fault slip rate, as there may be a considerable time lag between the fan stabilization and incision. The age of $\mathrm{T} 1$ should provide a maximum slip rate, as the latest time at which the F1-T1 riser displacement would start accumulating is the abandonment age of T1 [Cowgill, 2007]. A $~ 1 \mathrm{~m}$ deep sampling pit was excavated into the F1 and T1 surfaces. Two samples were taken from F1 at 50 and $60 \mathrm{~cm}$ depth (Figure 16). Three samples were taken from T1 at depths of 30, 60, and $94 \mathrm{~cm}$. 

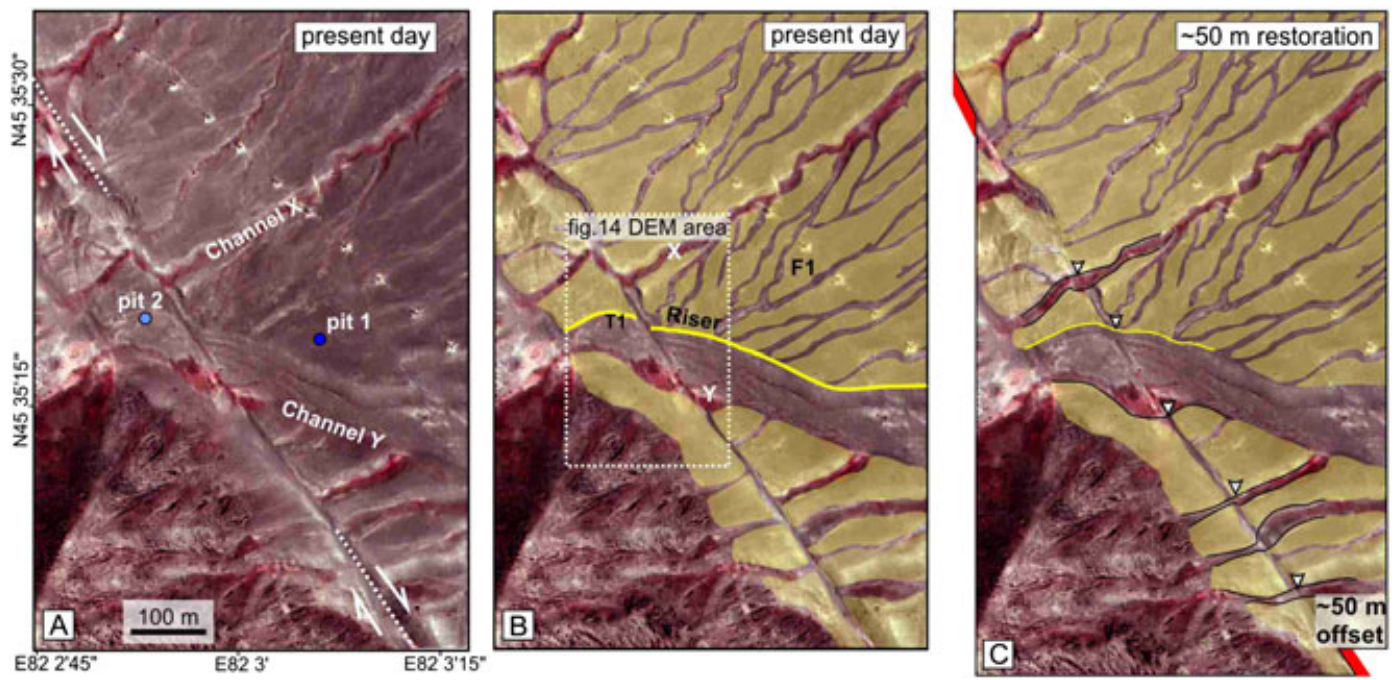

Figure 13. The Dzhungarian fault, showing right laterally offset late Quaternary features (1 m pixel resolution Kompsat-2 satellite imagery, see Figure 4 for regional location). Brighter red pixels indicate present-day vegetated river channels, which are offset right laterally by tens of meters as they cross the NW-SE trending fault. (a) Image showing the F1 fan surface and T1 terrace surfaces and their corresponding OSL sample pit locations (blue circles). Channel Y riser is marked in yellow. (b) Present-day interpretation showing the F1 drainage pattern and both the right laterally displaced Channel $\mathrm{X}$ and riser of Channel Y. (c) Restoration of $\sim 50 \mathrm{~m}$ right-lateral displacement realigns Channel X and the Channel Y riser, to their respective courses. To the SE, a further series of small river channels are also realigned to their consecutive mountain catchments SW of the fault.

[33] Sediment exposed in the F1 sampling pit comprises angular to subangular coarse gravel clasts of quartz-rich composition, supported by a fine silt matrix. We selected a horizon with relatively few gravel clasts for sampling (Figure 16). Sediment exposed in the T1 sampling pit comprises an upper $\sim 20 \mathrm{~cm}$ horizon of soil containing infrequent subangular gravel pebbles. Beneath this upper layer, the sediment comprises coarse subangular to angular clasts and infrequent small boulders, supported in a fine silt matrix. The T1 material shows a greater degree of stratification to that of the F1 material, with centimeter thick horizons of fine gravel that intersperse the material at irregular intervals.

[34] We interpret the F1 stratigraphy as typical alluvial fan sediments and the T1 stratigraphy to be representative of a paleo-channel deposit that was abandoned when the river gained more erosive power. Despite care taken to excavate pits to avoid signs of recent erosion or deposition, in light of the OSL ages (Table 1; samples X5329, X5330, and $\mathrm{X} 5331$ ), we find that the T1 material is much younger than the age of the likely abandonment event and may result from reworking of material or younger overbank deposition.

\subsection{OSL Dates}

\subsubsection{Sample Preparation}

[35] Luminescence dating was based on quartz grains extracted from the OSL sediment samples, and all preparations took place under low-intensity light-emitting diode lighting (emitting at $\sim 588 \mathrm{~nm}$ ). Laboratory procedures were designed to yield clean, sand-sized $(180-250 \mu \mathrm{m})$ grains of quartz for optical dating according to standard preparation methods, including wet sieving, $\mathrm{HCl}$ acid digestion, heavy liquid flotation using sodium polytungstate, and etching in concentrated hydrofluoric acid (40\%) to dissolve potassium feldspar minerals and to clean and remove the outer alpha-dosed layer of quartz grains. The latter residual grains were resieved to the original grain size range and mounted as multigrain monolayers of circa $4 \mathrm{~mm}$ diameter onto aluminum disks using a silicone oil adhesive.

\subsubsection{De Determination}

[36] To determine the age of our samples, two values are required: the equivalent dose $D e$ (which is the radiation level responsible for producing the luminescence signal) and the dose received per year (during burial). In this study the equivalent dose $(D e)$ was obtained using a singlealiquot regeneration measurement protocol [Murray and Wintle, 2000; Wintle and Murray, 2006] and OSL measurements were conducted using an automated TL/DA-15 Risø luminescence reader [Bøtter-Jensen, 1997; BøtterJensen et al., 2000].

[37] Optical stimulation for single aliquots was provided by clusters of blue light-emitting diodes (42 Nichia $470 \Delta$ $20 \mathrm{~nm}$ ) providing a sample stimulation power of $\sim 32$

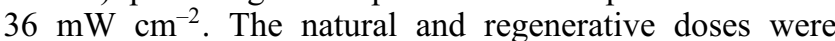
preheated at $26^{\circ} \mathrm{C}$ for $10 \mathrm{~s}$, and the fixed test doses (which are used to correct for any sensitivity changes) were preheated at a reduced temperature of $240^{\circ} \mathrm{C}$ for $10 \mathrm{~s}$, before optical stimulation.

[38] The absence of infrared-sensitive minerals (e.g., feldspars) was checked and confirmed using an infrared bleach $(50 \mathrm{~s})$ provided by a solid state laser diode $(830 \Delta 10$ $\mathrm{nm} ; 1 \mathrm{~W} \mathrm{~cm}^{2}$ ) at $50^{\circ} \mathrm{C}$ for $100 \mathrm{~s}$ before blue light stimulation [Banerjee et al., 2001]. The ultraviolet OSL emission at $\sim 370 \mathrm{~nm}$ was detected using an Electron Tubes Ltd 9235QA photomultiplier tube fitted with a blue-green sensitive bialkali photocathode and either $7.5 \mathrm{~mm}$ of Hoya U-340 glass filter or two Corning U-340 glass filters. 


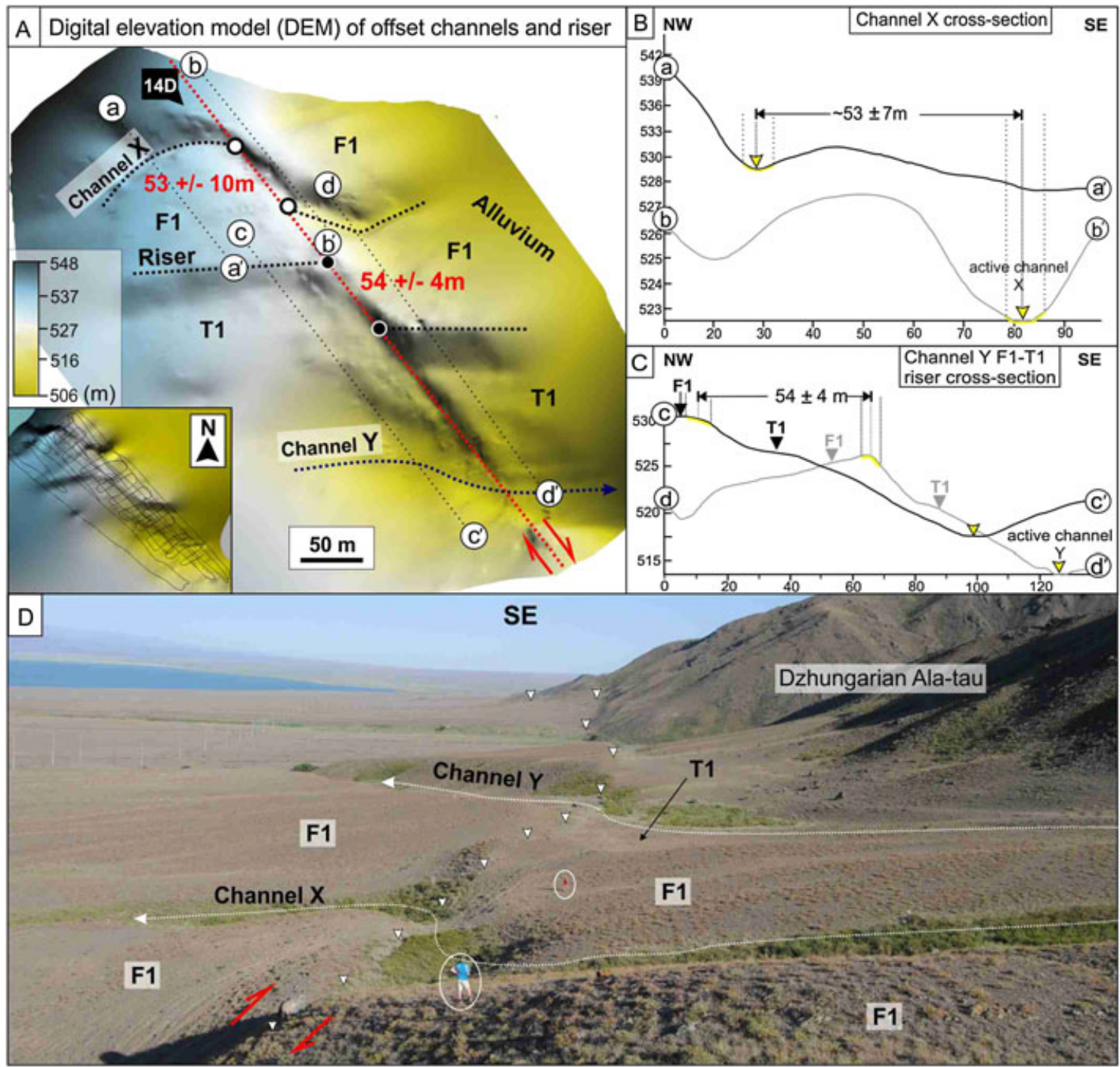

Figure 14. The Dzhungarian fault, Lake Alakol slip-rate site. (a) Kinematic GPS derived, digital elevation model (DEM) of the Dzhungarian fault opposite Lake Alakol, artificially illuminated from the NE. The DEM was made by fitting a surface of minimum curvature to the differential GPS elevation points shown in the inset map. A $\sim 54 \pm 4 \mathrm{~m}$ of right-lateral slip restores the offset river riser of Channel Y, SW, and NE of the Dzhungarian fault (the piercing points for this restoration are shown as black circles outlined in white). A $\sim 53 \pm 7 \mathrm{~m}$ of right-lateral slip restores the thalweg of the active Channel $\mathrm{X}, \mathrm{SW}$, and NE of the Dzhungarian fault (the piercing points for this restoration are shown as white circles outlined in black). (b, c) Topographic profiles across Channel X and the F1-T1 riser, respectively; yellow profile sections delimit the minimum and maximum deviations from the "best" piercing point and are used to estimate offset errors (see section 5.1). (d) Photo facing $\sim \mathrm{SE}$ along strike from $45^{\circ} 35^{\prime} \mathrm{N}, 82^{\circ} 02^{\prime} \mathrm{E}$, showing the right laterally offset Channels X (foreground) and Y (background).

[39] Laboratory doses used for constructing dose response curves were given using a calibrated ${ }^{90} \mathrm{Sr} /{ }^{90} \mathrm{Y}$ beta source housed within the reader. At least 12 disks were prepared from each sample, and following measurement of the natural signal, a dose response curve was constructed from six to eight dose points including a zero dose point and a replicate measurement of the lowest regenerative dose.

\subsubsection{Dose Rate and Age Determination}

[40] The environmental gamma and beta components of the dose rate result from the radioactive decay series of ${ }^{238} \mathrm{U}$, ${ }^{232} \mathrm{Th}$, and ${ }^{40} \mathrm{~K}$ within the sediment. The concentrations of these parent isotopes were obtained by inductively coupled plasma mass spectroscopy (ICP-MS/AES) using a lithium metaborate/tetraborate fusion. These concentrations were converted to dose rates according to attenuation factors proposed by Adamiec and Aitken [1998], using corrections for grain size [Mejdahl, 1979] and water content [Zimmerman, 1971]. The cosmic ray dose was calculated according to standard data reported by Prescott and Hutton [1994], taking into account the height and density of the overburden, as well as the geomagnetic latitude and elevation of the site. Dose rates and ages for each sample are presented in Table 1.

[41] We note that the quartz sensitivity of all samples was generally low. Samples X5331 and X5332 showed 

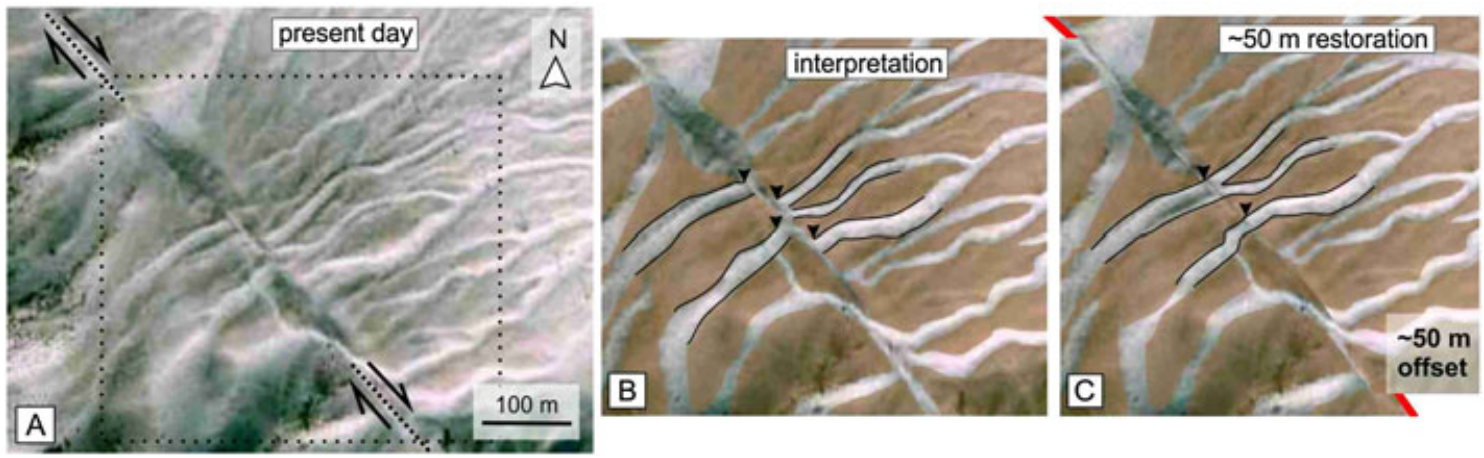

Figure 15. Satellite image (source: http://earth.google.com) at $45^{\circ} 36^{\prime} \mathrm{N}, 82^{\circ} 01^{\prime} \mathrm{E}, \sim 30 \mathrm{~km}$ further $\mathrm{NW}$ along strike of our slip-rate site near Lake Alakol (see Figure 4 for regional location), showing right laterally offset channels as they cross the Dzhungarian fault. Black triangles denote the piercing points used to restore $\sim 50 \mathrm{~m}$ of slip, which aligns the channels to their mountain catchments SW of the fault.

widely scattered palaeodose values and therefore are probably affected by incomplete resetting of the OSL signal at deposition. For this reason, we are cautious of interpreting the sample X5332 from the F1 pit. We also note that the water content of the samples was generally very low $(1 \%-3 \%)$.

\subsection{Slip Rate}

[42] As mentioned in section 5.2, the OSL ages of samples X5329, X5330, and X5331 from the T1 pit are much younger than the age of the likely abandonment event. The sampled material may have been affected by reworking of material or be a younger overbank deposit. We therefore do not discuss these dates any further.

[43] To calculate a slip rate, we use the measurement of offset recorded by the best defined geomorphic feature, the F1-T1 riser, and an error estimate defined by the maximum

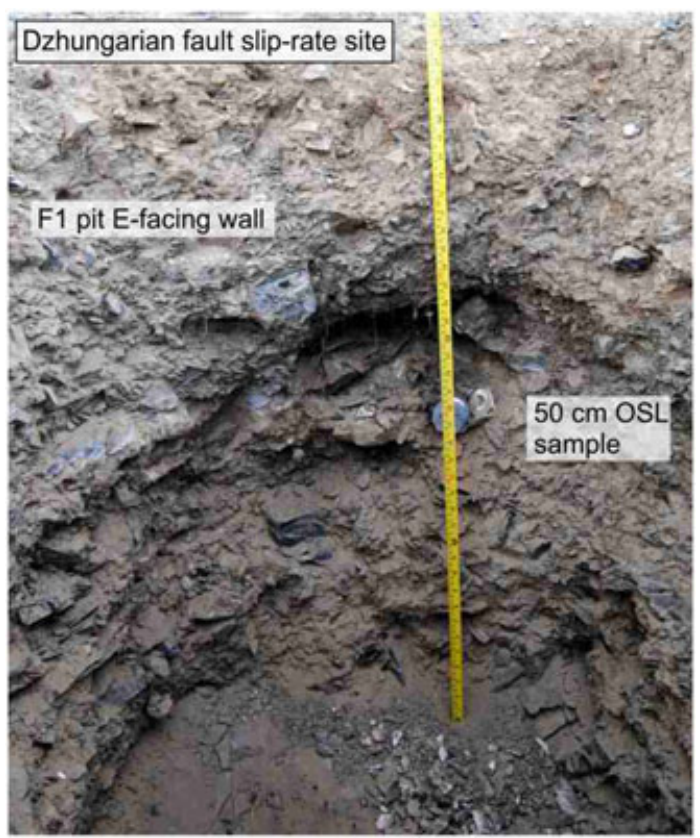

Figure 16. F1 pit E-facing wall, OSL sample at $50 \mathrm{~cm}$ depth. Pit location $\left(45^{\circ} 35^{\prime} \mathrm{N}, 82^{\circ} 02^{\prime} \mathrm{E}\right)$. observed error in offset measurement at the same slip-rate site, $53 \pm 7 \mathrm{~m}$. We divide this offset by the age of our most reliable F1 sample age, $25.7 \pm 5.8 \mathrm{ka}$ (sample X5333, Table 1), which shows little paleodose scatter and has a smaller estimated age error. This yielded a minimum average horizontal right-lateral slip rate of $2.2 \pm 0.8 \mathrm{~mm} / \mathrm{yr}$.

[44] The lateral displacement measurements are difficult to determine with absolute certainty as channel edges are often diffused (e.g., Channel X) and sometimes vegetated. A similar amount of right-lateral displacement, however, was recorded by a series of consecutive small alluvial channels $\sim 2.5 \mathrm{~km}$ further NW (Figure 15), indicating that slip along the fault, at least through the central section, has been consistent during the late Quaternary and that the timing of fan incision was synchronous along the length of the Dzhungarian Ala-tau.

[45] Although our preferred age of $25.7 \pm 5.8 \mathrm{ka}$ for the abandoned alluvial fan, F1, is based on a single sample, the age correlates well with the abandonment of the most recent alluvial fans in the Gobi-Altai of southern Mongolia at 20 ka [e.g., Ritz et al., 1995; Vassallo et al., 2005]. In the GobiAltai, this abandonment age has been linked to hydrological changes caused by the last glacial maximum, a regional climatic change, which may also have affected the landscape of SE Kazakhstan in a similar way. By contrast, based on an assumed age of $10 \mathrm{ka}$, Shen et al. [2003] calculate a slip rate of $\sim 5 \mathrm{~mm} / \mathrm{yr}$ from alluvial fans displaced by $\sim 50 \mathrm{~m}$ by the NW-SE Dzhungarian fault and $\sim 1-1.4 \mathrm{~mm} / \mathrm{yr}$ in the far SE section of the fault, near the Borohoro mountains (Figure 17). However, it is likely that the $10 \mathrm{ka}$ age of the displaced fan assumed by Shen et al. [2003] is too young and therefore yields a slip rate that is too high for the Dzhungarian fault. Our late Quaternary slip rate agrees well with the estimated geodetic slip rate of $\sim 3 \pm 1 \mathrm{~mm} / \mathrm{yr}$ [England and Molnar, 1997].

\section{Discussion}

[46] In the previous sections, we have used a combination of remote and field observations to reveal aspects of the structure and geomorphology of the Dzhungarian fault. We now discuss these observations in context of the regional tectonic setting and speculate on the role of the Dzhungarian 
Table 1. Values Used to Calculate Luminescence Ages From the Dzhungarian Fault, SE Kazakhstan ${ }^{\text {a }}$

\begin{tabular}{cccccc}
\hline Sample & Depth (m) & Deposit & Equivalent Dose (Gy) & Dose Rate (mGy/yr) & Age (ka) \\
\hline$X 5329$ & 0.30 & T1 & $4.14 \pm 1.00$ & $3.77 \pm 0.50$ & $1.1 \pm 0.3$ \\
$X 5330$ & 0.94 & T1 & $7.79 \pm 1.6$ & $4.01 \pm 0.22$ & $1.9 \pm 0.4$ \\
$X 5331$ & 0.60 & T1 & $16.65 \pm 4.79$ & $4.19 \pm 0.23$ & $4.0 \pm 1.2$ \\
$X 5332$ & 0.60 & F1 & $56.52 \pm 26.91$ & $3.34 \pm 0.17$ & $16.9 \pm 8.1$ \\
$X 5333$ & 0.50 & F1 & $89.40 \pm 19.47$ & $3.47 \pm 0.18$ & $25.7 \pm 5.8$ \\
\hline
\end{tabular}

${ }^{a}$ Measurements were made on dried, homogenized, and powdered material by inductively coupled plasma mass spectroscopy (ICP-MS/AES) with an assigned systematic uncertainty of $\pm 5 \%$. Dry beta dose rates calculated from these activities were adjusted for the measured field water content expressed as a percentage of the dry mass of the sample. For deposit descriptions, see section 5.2.

fault in accommodating larger-scale deformation related to the ongoing India-Eurasia collision, as well as its potential for seismic hazard.

\subsection{Possible Rotations}

[47] There are two possible roles the NW-SE right-lateral Dzhungarian fault may play in accommodating N-S shortening related to the India-Eurasia collision. The first is by counterclockwise $(\mathrm{CC})$ rotations about a vertical axis, the second is in relation to conjugate left-lateral faulting.

[48] Along the Dzhungarian fault (close to Uch Aral, Figure 3), GPS velocities relative to stable Eurasia are NNW-SSE and are therefore oblique to the NW-SE strike of the fault. Although there is no earthquake focal mechanism data for the Dzhungarian fault, we speculate that the slip vector of a right-lateral strike-slip earthquake would be more westerly than the GPS vectors close to Uch Aral. Similarly discrepant earthquake slip vectors and GPS velocities are observed in the Mongolian Altai, where rotation of paleomagnetic declinations confirm that the NW-SE and $\mathrm{N}-\mathrm{S}$ right-lateral strike-slip faults accommodate shortening by $\mathrm{CC}$ rotation [Bayasgalan et al., 2005].

[49] We can assess the expected slip rate on the Dzhungarian fault associated with $\mathrm{N}-\mathrm{S}$ compression and $\mathrm{CC}$

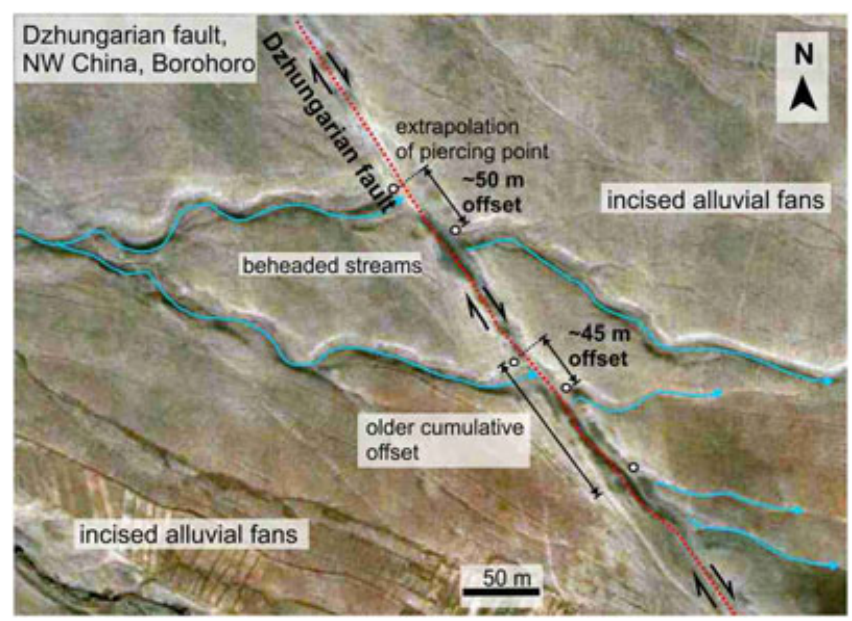

Figure 17. Satellite image (source: http://earth.google. com) showing the continuation of the NW-SE Dzhungarian fault in NW China, near the Borohoro mountains $\left(44^{\circ} 29^{\prime} \mathrm{N}\right.$, $83^{\circ} 02^{\prime} \mathrm{E}$ ) see Figure 3 for regional location. Incised channels in abandoned late Quaternary alluvial fans are displaced right laterally by $\sim 45-50 \mathrm{~m}$ where they cross the fault. A cumulative offset of $\sim 100 \mathrm{~m}$ is also observed. rotation with a simple model (Figure 18). To achieve the GPS convergence rate, $\mathrm{S}$, across $\sim 10,000 \mathrm{~km}^{2}$ of the western Dzhungarian Ala-tau ( $\sim 2 \mathrm{~mm} / \mathrm{yr}$, Figure 3) [Zubovich et al., 2010], with an angle, $\phi$, of $\sim 35^{\circ}$ between the fault strike and GPS vector azimuth, and an average across-strike distance, D, between the major NW-SE faults of $\sim 150 \mathrm{~km}$ (found using the spacing between major NW-SE faults in Figure 1) requires a total slip rate of $\sim 3.5 \mathrm{~mm} / \mathrm{yr}$ (Figure 20); which is within error of our minimum slip-rate estimate on the Dzhungarian fault determined by OSL dating. These calculations also yield an estimated rotation rate, $\Theta$, of $\sim 0.45^{\circ} / \mathrm{Ma}$ for the faults in the Dzhungarian Ala-tau.

[50] Alternatively, N-S shortening may be accommodated by conjugate left-lateral strike-slip faulting. Buckman and Aitchison [2004] mapped a series of left-lateral strike-slip faults $\sim 25 \mathrm{~km}$ NE of the Dzhungarian fault, in the Kertau mountains of western China (Figure 3). Early analog models of continental indentation in Central Asia [Tapponnier et al., 1982; Davy and Cobbold, 1988; Cobbold and Davy, 1988; Jolivet et al., 1990] suggested that large-scale conjugate strike-slip faulting is important in accommodating IndiaEurasia convergence by lateral extrusion. Currently, there is no paleomagnetic data in the Dzhungarian Ala-tau to address the relative importance of these two roles in accommodating overall N-S shortening.

\subsection{Earthquake Recurrence Times and Seismogenic Potential}

[51] The Dzhungarian fault has no record of significant historical or modern earthquakes (Figures $1 \mathrm{~b}$ and 2). Despite this, we found evidence for one possible paleo-earthquake rupture in the central section of the fault (see section 4). As described in section 3.2.1, the central section of the Dzhungarian fault is characterized by shorter $(\sim 30 \mathrm{~km}$ length) fault segments, with "partitioning" of strike-slip and reverse components of motion onto each separate subparallel fault strand.

[52] If we assume that the possible paleo-earthquake rupture ( $L=32 \mathrm{~km}, \bar{u}=2.3 \mathrm{~m}, M w 7)$ observed in the field is representative of the shorter fault segments that characterize the central section of the Dzhungarian fault, then with a small fraction of the estimated average late Quaternary slip rate of $2.2 \pm 0.8 \mathrm{~mm} / \mathrm{yr}$, which is likely to be accommodated by only the partitioned reverse component of slip, we might expect $M w \sim 7$ earthquake recurrence intervals of several thousands of years for equivalent segments along this central section of the fault. Such long repeat times can explain why we do not observe multiple paleo-earthquake ruptures of $\sim 30 \mathrm{~km}$ length. 


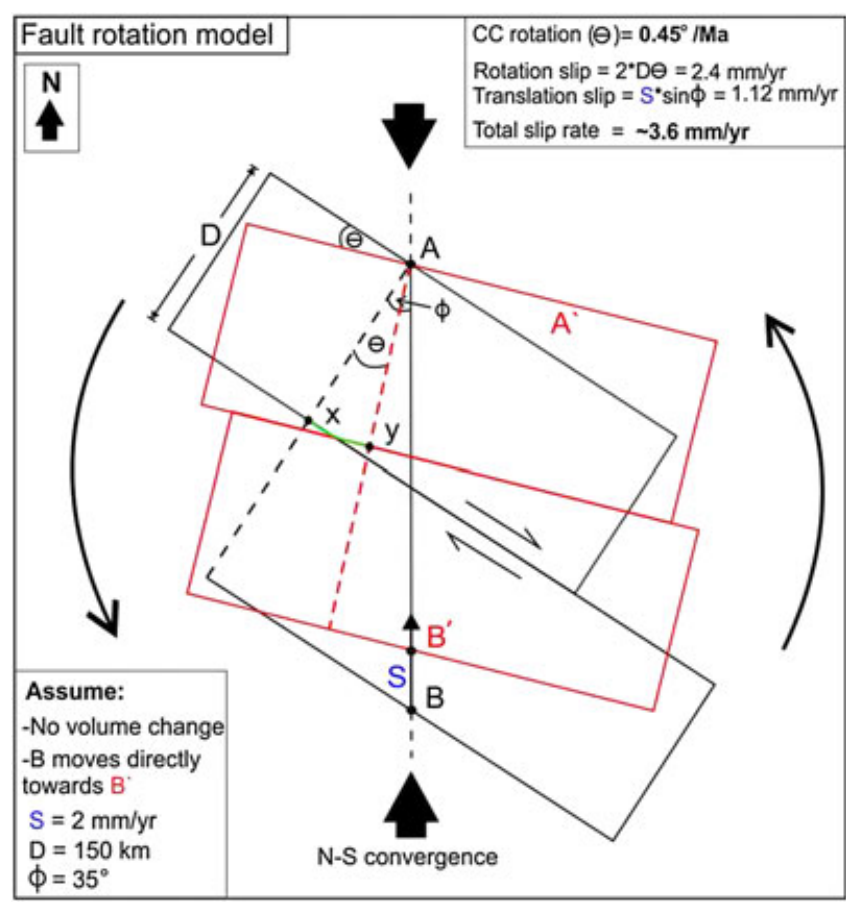

Figure 18. Fault rotation model for the NW-SE rightlateral Dzhungarian fault. The black blocks denote the original fault orientation; the red, shaded blocks indicate the fault orientation after right-lateral slip and counterclockwise (CC) rotation. Overall shortening (large black arrows) is N$\mathrm{S}$ and has a rate, $\mathrm{S}$, of $\sim 2 \mathrm{~mm} / \mathrm{yr}$ [Zubovich et al., 2010] (see text for details). Our estimate of total slip, $\sim 3.6 \mathrm{~mm} / \mathrm{yr}$, using this rotation model can account for both the rotation of blocks from orientation A and B (black blocks) to orientation $\mathrm{A}^{\prime}$ and $\mathrm{B}^{\prime}$ (red blocks), about fixed points $\mathrm{A}$ and $\mathrm{B}$ (black circles) and also translation of the blocks (northward movement from $\mathrm{B}$ to $\mathrm{B}^{\prime}$ ) required to maintain a constant volume. This total slip-rate estimate is consistent with our minimum estimate of late Quaternary slip on the Dzhungarian fault from OSL dating and yields a $\mathrm{CC}$ rotation rate, $\Theta$, of $0.45^{\circ} / \mathrm{Ma}$.

[53] Significantly, however, the $\sim 100 \mathrm{~km}$ long NW and SE sections of the Dzhungarian fault show very little segmentation and have the potential to generate greater magnitude earthquakes (e.g., $M w 7.5$ or more). If these sections also fail in $M w 7$ events, involving 2-3 $\mathrm{m}$ of slip, the repeat time between events on any $\sim 30 \mathrm{~km}$ length of the fault would be $\sim 1000$ years at the slip rate we determine. Surface ruptures from earthquakes in cold and arid parts of central Asia are preserved in the landscape for $\geq 1000$ years [e.g., Baljinnyam et al., 1993]. Therefore, the absence of paleoruptures preserved along the Dzhungarian fault instead suggests the fault fails in occasional larger earthquakes. The fact that we do not observe $100 \mathrm{~km}$ long ruptures attests to the long repeat times for such events, and with a long interval since the last event, evidence of which is not likely to remain preserved clearly in the landscape over several thousands of years, despite very low rates of erosion. Despite the long repeat times expected for such large strike-slip earthquakes, strike-slip events of $M w \geq 8$ with over $100 \mathrm{~km}$ of surface ruptures are known from the northern Tien Shan region (e.g., the Ms 8.2 1911 Chon-Kemin earthquake, see section 2.3).

\section{Conclusions}

[54] The $\sim 300 \mathrm{~km}$ long Dzhungarian fault is an example of a major active right-lateral strike-slip fault of the northern Tien Shan region. By placing this fault in context of what is known about the active tectonics, GPS velocities, and the record of modern and historical seismicity, and by establishing a minimum late Quaternary slip rate of $2.2 \pm 0.8 \mathrm{~mm} / \mathrm{yr}$, we show that this fault plays a key role in accommodating strain related to the ongoing India-Eurasia collision and may be associated with counterclockwise rotations about a vertical axis.

[55] Observations of the structure and geomorphology indicate that the Dzhungarian fault can be characterized by three $\sim 100 \mathrm{~km}$ long sections based on variation in strike direction: the SE, central, and NW sections. Both the SE and NW fault sections show little segmentation; the SE fault section is almost pure strike slip, whereas the geomorphology of the NW fault section is subdued and is likely to have a lower slip rate than that of the central and SE sections. By contrast, the central section of the Dzhungarian fault is more segmented with separate components (reverse and strike slip) of the overall slip "partitioned" onto subparallel fault strands.

[56] These observations of the overall fault structure have important implications for the seismogenic potential of the Dzhungarian fault. Shorter segments of the central section of the Dzhungarian fault that rupture in partitioned reverse slip earthquakes are likely to accommodate only a fraction of the overall estimated slip rate $(2.2 \pm 0.8 \mathrm{~mm} / \mathrm{yr})$; earthquakes of $M w \sim 6-7$ on such segments therefore require long (e.g., several thousands of years) time periods to accumulate enough strain to rupture. Similarly, the long, unsegmented fault sections of the NW and SE Dzhungarian fault are likely to accumulate strain over equally long time periods; an event rupturing a $100 \mathrm{~km}$ long section of the fault, however, has the potential to generate a very large earthquake $M w \geq 7$, examples of which are known from strike-slip faults of the northern Tien Shan region.

[57] Acknowledgments. We thank the Royal Society International Travel Grant, Mike Coward Fund of the Geological Society of London, Percy Sladen Fund of the Linnean Society, The Gilchrist Educational Trust, and the Earth and Space Foundation for their support in funding this project. GEC's doctoral studentship is funded by the National Environmental Research Council through NCEO, COMET, and the NERC-ESRC funded Earthquakes without Frontiers (EWF) Project. RTW is supported by a University Research Fellowship awarded by the Royal Society. KOMPSAT-2 imagery was obtained through a Category-1 award from the European Space Agency. DigitalGlobe high-resolution satellite imagery was obtained from Google Earth. SRTM was obtained from CGIAR-CSI, Landsat, and ASTER imagery was obtained from the Global Land Cover Facility (GLCF) University of Maryland. Great thanks to Ivan and Atyr for their support in the field and helping with the logistics of the field work, and to Natalya Mikhailova at the Kazakhstan National Data Centre (KNDC). This work benefited from useful discussions with Timothy Craig and Alistair Sloan. We also thank D. Peat for help with OSL sample preparation.

\section{References}

Abdrakhmatov, K., K. D. Djanuzakov, and D. Delvaux (2002), Active tectonics and seismic hazard of the Issyk-Kul basin in the Kyrgyz TianShan. Lake Issyk-Kul: Its natural environment, in Lake Issyk-Kul: Its 
Natural Environment, vol. 13, edited by J. Klerkx and B. Imanackunov, pp. 147-160, NATO Science Series, Kluwer, Dordrecht.

Abdrakhmatov, K., R. Weldon, S. Thompson, D. W. Burbank, C. Rubin, M. Miller, and P. Molnar (2001), Onset, style and current rate of shortening in the central Tien Shan, Kyrgyz Republic, Geol. Geophys., 42, $1585-1609$.

Abdrakhmatov, K., et al. (1996), Relatively recent construction of the Tien Shan inferred from GPS measurements of present-day crustal deformation rates, Nature, 384, 450-453.

Adamiec, G., and M. Aitken (1998), Dose-rate conversion factors: New data, Ancient TL, 16(2), 37-50.

Avouac, J. P., P. Tapponnier, M. Bai, H. You, and G. Wang (1993), Active thrusting and folding along the Northern Tien Shan and Late Cenozoic rotation of the Tarim relative to Dzungaria and Kazakhstan, J. Geophys. Res., 98(B4), 6755-6804.

Baljinnyam, I., et al. (1993), Ruptures of Major Earthquakes and Active Deformation in Mongolia and its Surroundings, Geological Society of America Memoir 181, Boulder, Colorado.

Banerjee, D., A. S. Murray, L. Bøtter-Jensen, and A. Lang (2001), Equivalent dose estimation using a single aliquot of polymineral fine grains, Radiat. Meas., 33(1), 73-94.

Bayasgalan, A., J. Jackson, J. F. Ritz, and S. Carretier (1999a), Field examples of strike-slip fault terminations in Mongolia and their tectonic significance, Tectonics, 18(3), 394-411.

Bayasgalan, A., J. Jackson, J. F. Ritz, and S. Carretier (1999b), 'Forebergs', flower structures, and the development of large intra-continental strikeslip faults: The Gurvan Bogd fault system in Mongolia, J. Struct. Geol., $21(10), 1285-1302$.

Bayasgalan, A., J. Jackson, and D. McKenzie (2005), Lithosphere rheology and active tectonics in Mongolia: Relations between earthquake source parameters, gravity and GPS measurements, Geophys. J. Int., 163, 1151-1179, doi:10.1111/j.1365-246X.2005.02764.x.

Berberian, M., J. A. Jackson, M. Qorashi, M. Talebian, M. Khatib, and K. Priestley (2000), The 1994 Sefidabeh earthquakes in eastern Iran: Blind thrusting and bedding-plane slip on a growing anticline, and active tectonics of the Sistan suture zone, Geophys. J. Int., 142(2), 283-299.

Bogdanovich, K. I., I. M. Kark, B. Y. Korol'kov, and D. I. Mushketov (1914), Earthquake in northern district of Tien Shan, 22 December 1911 (4 January 1911), paper presented at Geology Committee, New series, 89, St. Petersburg (in Russian, extended abstract in Frence)

Bøtter-Jensen, L. (1997), Luminescence techniques: Instrumentation and methods, Radiat. Meas., 27(5-6), 749-768.

Bøtter-Jensen, L., E. Bulur, G. A. T. Duller, and A. S. Murray (2000), Advances in luminescence instrument systems, Radiat. Meas., 32(5), 523-528.

Buckman, S., and J. C. Aitchison (2004), Tectonic evolution of Palaeozoic terranes in West Junggar, Xinjiang, Northwest China, in Aspects of the Tectonic Evolution of China, Special Publ. 226, edited by J. G. Malpas et al., pp. 101-129, Geological Society, London.

Bullen, M. E., D. W. Burbank, J. I. Garver, and K. Abdrakhmatov (2001), Late Cenozoic tectonic evolution of the northwestern Tien Shan: New age estimates for the initiation of mountain building, Geol. Soc. Am. Bull., 113(12), 1544-1559.

Bullen, M. E., D. W. Burbank, and J. I. Garver (2003), Building the Northern Tien Shan: Integrated thermal, structural, and topographic constraints, J. Geol., 111(2), 149-165.

Burtman, V. S. (1975), Structural geology of Variscan Tien Shan, USSR, Am. J. Sci., 275, 157-186.

Burtman, V. S., S. F. Skobelev, and P. Molnar (1996), Late Cenozoic slip on the Talas-Ferghana fault, the Tien Shan, central Asia, Geol. Soc. Am. Bull., 108(8), 1004-1021.

Buslov, M. M., J. Klerkx, K. Abdrakhmatov, D. Delvaux, V. Y. Batalev, O. A. Kuchai, B. Dehandschutter, and A. Muraliev (2003), Recent strikeslip deformation of the northern Tien Shan, in Intraplate Strike-Slip Deformation Belts, Special Publications 210, edited by F. Stori, R. E. Holdsworth, and F. Salvini, pp. 53-64, Geological Society, London.

Cobbold, P. R., and P. Davy (1988), Indentation tectonics in nature and experiments, 2, Central Asia, Bull. Geol. Inst. Univ. Uppsala, 14, $129-141$.

Cowgill, E. (2007), Impact of riser reconstructions on estimation of secular variation in rates of strike-slip faulting: Revisiting the Cherchen River site along the Altyn Tagh Fault, NW China, Earth Planet. Sci. Lett., 254, 239-255.

Davy, P., and P. R. Cobbold (1988), Indentation tectonics in nature and experiment. 1. Experiment scaled for gravity, Bull. Geol. Inst Univ. Uppsala, 14, 129-141.

De Grave, J., M. M. Buslov, and P. van den Haute (2007), Distant effects of India-Eurasia convergence and Mesozoic intracontinental deformation in Central Asia: Constraints from apatite fission-track thermochronology, $J$. Asian Earth Sci., 29, 188-204.
Delvaux, D., K. E. Abdrakhmatov, I. N. Lemzin, and A. L. Strom (2001), Landslide and surface breaks of the 1911 M 8.2 Kemin Earthquake, Landslides, 42(10), 1583-1592.

DeMets, C., R. G. Gordon, D. F. Argus, and S. Stein (1990), Current plate motions, Geophys. J. Int., $101(2), 425-478$.

Engdahl, E. R., R. van der Hilst, and B. Raymond (1998), Global teleseismic earthquake relocation with improved travel times and procedures for depth determination, Bull. Seismol. Soc. Am., 88, 722-743.

England, P., and P. Molnar (1997), The field of crustal velocity in Asia calculated from Quaternary rates of slip on faults, Geophys. J. Int., 130(3), 551-582.

Florensov, N. A., and V. P. Solonenko (eds.) (1963), The Gobi-Altay Earthquake (in Russian), English Translation, Israel Program for Scientific Translation, Jerusalem, 1965, pp. 391-424, U.S. Dept. of Commerce, Washinton, D.C.

Ghose, S., R. J. Mellors, A. M. Korjenkov, M. W. Hamburger, T. L. Pavlis, G. L. Pavlis, M. Omuraliev, E. Mamyrov, and A. R. Muraliev (1997) The Ms $=7.31992$ Suusamyr, Kyrgyzstan, earthquake in the Tien Shan 2. Aftershock focal mechanisms and surface deformation, Bul. Seismol. Soc. Am., 87(1), 23-38.

Glorie, S., J. De Grave, M. M. Buslov, M. A. Elburg, D. F. Stockli, A. Gerdes, and P. Van den haute (2010), Multi-method chronometric constraints on the evolution of the Northern Kyrgyz Tien Shan granitoids (Central Asian Orogenic Belt): From emplacement to exhumation, $J$. Asian Earth Sci., 38, 131-146.

Hay, M. B. (1888), The earthquakes of May and June, 1887, in the Verny (Vernoe) District, Russian Turkestan, and their consequences, paper presented at Royal Geographical Society and Monthly Record of Geography, pages 638-646. JSTOR.

Hendrix, M. S., S. A. Graham, A. R. Carroll, E. R. Sobel, C. L. Mcnight, B. J. Schulein, and Z. Wang (1992), Sedimentary record and climatic implications of recurrent deformation in the Tian Shan: Evidence from Mesozoic strata of the North Tarim, South Junggar, and Turpan basins, Northwest China, Geol. Soc. Am. Bull., 104(1), 53-79.

Hollingsworth, J., J. Jackson, R. Walker, M. Reza Gheitanchi, and M. Javad Bolourchi (2006), Strike-slip faulting, rotation, and along-strike elongation in the Kopeh Dagh mountains, NE Iran, Geophys. J. Int., 166(3), 1161-1177.

Jolivet, L., P. Davy, and P. R. Cobbold (1990), Right-lateral shear along the Northwest pacific margin and the India-Eurasia collision, Tectonics, 9, 1409-1419.

Kondorskaya, N. V., and N. V. Shebalin (1977), New Catalog of Strong Earthquakes in the USSR from Ancient Times to 1975 (in Russian), vol. 535, Nauka, Moscow.

Korjenkov, A. M., I. E. Povolotskaya, and E. Mamyrov (2007), Morphologic expression of Quaternary deformation in the Northwestern foothills of the Ysyk-Köl basin, Tien Shan, Geotectonics, 41, $130-148$.

Korjenkov, A. M., A. V. Bobrovskii, and E. M. Mamyrov (2010), Evidence for strong paleoearthquakes along the Talas-Fergana Fault near the KökBel Pass, Kyrgyzstan, Geotectonics, 44, 262-270.

Kuchay, V. K. (1969), Results of the repeated studies of ground deformations in the epicentral area of the Kebi earthquake (in Russian), Geol. Geophys. 8, 101-108.

Mejdahl, V. (1979), Thermoluminescence dating: Beta-dose attenuation in quartz grains, Archaeometry, 21(1), 61-72.

Mellors, R. J., F. L. Vernon, G. L. Pavlis, G. A. Abers, M. W. Hamburger, S. Ghose, and B. Iliasov (1997), The Ms = 7.31992 Suusamyr, Kyrgyzstan, earthquake: 1 . Constraints on fault geometry and source parameters based on aftershocks and body-wave modeling, Bull. Seismol. Soc. Am., 87(1), $11-22$.

Mohadjer, S., et al. (2010), Partitioning of India-Eurasia convergence in the Pamir-Hindu Kush from GPS measurements, Geophys. Res. Lett., 37 , L04305, doi:10.1029/2009GL041737.

Molnar, P., and K. E. Dayem (2010), Major intracontinental strike-slip faults and contrasts in lithospheric strength, Geosphere, 6, 444-467.

Molnar, P., and S. Ghose (2000), Seismic moments of major earthquakes and the rate of shortening across the Tien Shan, Geophys. Res. Lett., 27(16), 2377-2380

Murray, A. S., and A. G. Wintle (2000), Luminescence dating of quartz using an improved single-aliquot regenerative-dose protocol, Radiat. Meas., 32(1), 57-73.

Mushketov, I. V. (1890), Vemy Earthquake 28 May (9 June) 1887 [in Russian], p. 154, Commission of the Geology Committee, St. Petersburg.

Mushketov, I. V., and A. S. Survorin (1891), Materials for the Study of Earthquakes of Russia (in Russian), p. 62, Commission of the Geology Committee, St. Petersburg, Russia.

Oskin, M. E., and D. Burbank (2007), Transient landscape evolution of basement-cored uplifts: Example of the Kyrgyz Range, Tian Shan, $J$. Geophys. Res., 112, F03S03, doi:10.1029/2006JF000563. 
Prescott, J. R., and J. T. Hutton (1994), Cosmic ray contributions to dose rates for luminescence and ESR dating: Large depths and long-term time variations, Radiat. Meas., 23(2), 497-500.

Reigber, C., G. W. Michel, R. Galas, D. Angermann, J. Klotz, J. Y. Chen, A. Papschev, R. Arslanov, V. E. Tzurkov, and M. C. Ishanov (2001a), New space geodetic constraints on the distribution of deformation in Central Asia, Earth Planet. Sci. Lett., 191(1-2), 157-165, doi:10.1016/S0012$821 \mathrm{X}(01) 00414-9$

Reigber, C., G. W. Michel, R. Galas, D. Angermann, J. Klotz, J. Y. Chen, A. Papschev, R. Arslanov, V. E. Tzurkov, and M. C. Ishanov (2001b), New space geodetic constraints on the distribution of deformation in Central Asia, Earth Planet. Sci. Lett., 191(1), 157-165.

Ritz, J-F., E. T. Brown, D. L. Bourles, H. Philip, A. Schlupp, G. M. Raisbeck, F. Yiou, and B. Enkhtuvshin (1995), Slip rates along active faults estimated with cosmic-ray-exposure dates: Application to the Bogd fault, Gobi Altai, Mongolia, Geology, 23, 1019-1022.

Scholz, C. H. (1982), Scaling laws for large earthquakes: Consequences for physical models, Bull. Seismol. Soc. Am., 72(1), 1-14.

Selander, J., M. Oskin, C. Ormukov, and K. Abdrakhmatov (2012), Inherited strike-slip faults as an origin for basement-cored uplifts: Example of the Kungey and Zailiskey ranges, northern Tian Shan, Tectonics, 31(4), TC4026, doi:10.1029/2011TC003002.

Shen, Z.-K., M. Wang, Y. Li, D. D. Jackson, A. Yin, D. Dong, and P. Fang (2001), Crustal deformation along the Altyn Tagh fault system, western China, from GPS, J. Geophys. Res., 106(B12), 30,607-30,621, doi:10.1029/2001JB000349.

Shen, J., Y.-P. Wang, Y.-Z. Li, H. Jiang, and Z.-Y. Xiang (2003), The China Xinjiang Tianshan Boa fracture Late Quaternary dextral strike-slip motion feature, Seismol. Geol., 25(2), 183-194.

Simpson, D. W., and M. W. Hamburger (1981), Tectonics and seismicity of the Toktogul reservoir region, Kirgizia, USSR, J. Geophys. Res., 86(B1), $345-358$.

Sloan, R. A., J. A. Jackson, D. McKenzie, and K. Priestley (2011), Earthquake depth distributions in central Asia, and their relations with lithosphere thickness, shortening and extension, Geophys. J. Int., 185(1), 1-29, doi:10.1111/j.1365-246X.2010.04882.x.

Sobel, E. R., M. Oskin, D. Burbank, and A. Mikolaichuk (2006), Exhumation of basement-cored uplifts: Example of the Kyrgyz Range quantified with apatite fission track thermochronology, Tectonics, 25, TC2008, doi:10.1029/2005TC001809.

Suvorov, A. I. (1963), Main faults of Kazakhstan and Central Asia (in Russian), in Faults and Horizontal Movements of the Earth's Crust, Tr. Geol. Inst., 80, 173-237.
Suvorov, A. I. (1973), Deep Faults of Platforms and Geosynclines (in Russian), p. 213, Nedra, Moscow, Russia.

Tapponnier, P., and P. Molnar (1979), Active faulting and cenozoic tectonics of the Tien Shan, Mongolia, and Baykal regions, J. Geophys. Res., 84, 3425-3459, doi:10.1029/JB084iB07p03425.

Tapponnier, P., G. Peltzer, A. Y. Le Dain, R. Armijo, and P. R. Cobbold (1982), Propagating extrasing in Asia: New insights from simple experiments with plasticine, Geology, 10, 611-616.

Thomas, J. C., P. R. Cobbold, A. Wright, and D. Gapais (1996), Cenozoic Tectonics of the Tadzhik Depression, Central Asia, World and Regional Geology, pp. 191-207, Cambridge Univ. Press, New York.

Thompson, S. C., R. J. Weldon, C. M. Rubin, K. Abdrakhmatov, P. Molnar, and G. W. Berger (2002), Late Quaternary slip rates across the central Tien Shan, Kyrgyzstan, central Asia, J. Geophys. Res., 107, 2203, doi:10.1029/2001JB000596.

Trifonov, V. G. (1978), Late Quaternary tectonic movements of western and central Asia, Geol. Soc. Am. Bull., 89(7), 1059-1072.

Trifonov, V. G. (2004), Active faults in Eurasia: General remarks, Tectonophysics, 380, 123-130.

Vassallo, R., J.-F. Ritz, R. Braucher, and S. Carretier (2005), Dating faulted alluvial fans with cosmogenic ${ }^{10} \mathrm{Be}$ in the Gurvan Bogd mountain range (Gobi-Altay, Mongolia): Climatic and tectonic implications, Terra Nova, 17, 278-285.

Voitovich, V. S. (1969), Nature of the Dzungarian deep fault (in Russian), Tr. Geol. Inst., 183, 189.

Walker, R., J. Jackson, and C. Baker (2004), Active faulting and seismicity of the Dasht-e-Bayaz region, Eastern Iran, Geophys. J. Int., 157, 265-282.

Windley, B. F., M. B. Allen, C. Zhang, Z. Y. Zhao, and G. R. Wang (1990), Paleozoic accretion and Cenozoic redeformation of the Chinese Tien Shan Range, central Asia, Geology, 18(2), 128-131.

Wintle, A. G., and A. S. Murray (2006), A review of quartz optically stimulated luminescence characteristics and their relevance in single-aliquot regeneration dating protocols, Radiat. Meas., 41, 369-391.

Yang, S. M., J. Li, and Q. Wang (2008), The deformation pattern and fault rate in the Tianshan Mountains inferred from GPS observations, Sci. China. Ser. D, 51, 1064-1080.

Zimmerman, D. W. (1971), Thermoluminescent dating using fine grains from pottery, Archaeometry, 13(1), 29-52.

Zubovich, A. V., et al. (2010), GPS velocity field for the Tien Shan and surrounding regions, Tectonics, 29, TC6014, doi:10.1029/2010TC002772. 